\title{
MetKa FuRLan
}

\section{NOVI ETIMOLOŠKI SLOVAR SLOVENSKEGA JEZIKA KOT RASTOČI SPLETNI SLOVAR: DODATEK 2018}

Coвiss: 1.01

HTTPS://DOI.ORG/10.3986/JZ.v24I2.7102

\begin{abstract}
V prispevku se objavljajo nova gesla, ki bodo ob koncu leta 2018 dodana Novemu etimološkemu slovarju slovenskega jezika kot rastočemu spletnemu slovarju (2017-), dostopnemu na portalu Fran Inštituta za slovenski jezik Frana Ramovša.

Ključne besede: Novi etimološki slovar slovenskega jezika, spletni rastoči slovar, etimološki slovar, etimologija, slovenščina
\end{abstract}

\section{The New Slovenian Etymological Dictionary as a Growing Online}

\section{Dictionary: 2018 Additions}

This article presents the new headwords that at the end of 2018 will be added to Novi etimološki slovar slovenskega jezika (The New Slovenian Etymological Dictionary) as a growing online dictionary (2017-) available at the web portal Fran of the Fran Ramovš Institute of the Slovenian Language.

Keywords: Novi etimološki slovar slovenskega jezika, growing online dictionary, etymological dictionary, etymology, Slovenian

\section{UVOD}

Ko je na začetku leta 2014 z letnico 2013 izšel poskusni zvezek Novega etimološkega slovarja slovenskega jezika (Furlan 2013) in so bila leta 2017 njegova gesla pod istim naslovom objavljena na portalu Fran Inštituta za slovenski jezik Frana Ramovša 〈https://fran.si/207/nessj-novi-etimoloski-slovar-slovenskega-jezika//, je bil spletni etimološki slovar zasnovan kot rastoči, njegov obseg pa naj bi se večal v letnih intervalih. V tem prispevku objavljam sveženj novih gesel, ki bodo koncem leta 2018 zaradi drugačnega medija le leksikografsko, tj. formalno preoblikovana pridružena obstoječim 147.1

Odločitev, da se novi sveženj gesel objavi tudi v klasičnem papirnem mediju, preden bo priključen Novemu etimološkemu slovarju slovenskega jezika kot spletnemu rastočemu slovarju, temelji predvsem na dobro znanem dejstvu, da je papirnati medij v primerjavi s spletnim še vedno najbolj zanesljiv in verodostojen dokument o stanju raziskanosti določene tematike $\mathrm{v}$ času svoje prve objave in

Prispevek je nastal v okviru programa P6-0038, ki ga financira ARRS.

$1 \quad$ Število gesel je v spletnem rastočem Novem etimološkem slovarju slovenskega jezika v primerjavi s številom v poskusnem zvezku večje za 1, ker mu je bilo zaradi boljše preglednosti obravnavanega slovenskega gradiva dodano še 1 kazalčno geslo. 
tudi nadaljnjih. Papirnati medij dopušča popravke in dopolnila le v obliki ponovnih dopolnjenih in/ali popravljenih izdaj predhodnih dokumentov. To pa omogoča kronološko sledljivost sprememb prvotnega besedila in ne nazadnje spremljanje razvoja strokovnih mnenj. Nasprotno pa imajo spletne objave zaradi možnosti stalnega spreminjanja dokumenta in neohranjanja prvotnega, ki bi omogočal kronološko prepoznavaje sprememb, status začasnega in zato nedokončnega besedila.

Leksikografsko prikazovanje etimološko obravnavanega besedja sledi zasnovi, predstavljeni v poskusnem zvezku, ki zagovarja negnezdnost gesel (Furlan 2013: 61-110). Gesla so nastajala pretežno v januarju 2018, popravljala, izboljševala in dopolnjevala pa so se do konca redakcije teh Jezikoslovnih zapiskov. Od 70 geselskih iztočnic jih 54 v Bezlajevem Etimološkem slovarju slovenskega jezika I-V ni bilo obravnavanih. Med 70 gesli je 18 kazalčnih. Izbor geselskih iztočnic ne sledi posebni sistematiki in je paberkovalnega značaja, odraža pa namen, da se v sodobno etimološko stroko vključi take slovenske besede, ki ali etimološko še niso bile obravnavane ali so bile do sedaj obravnavane $\mathrm{v}$ manj ustreznem, praviloma pomensko preširokem kontekstu ali pa je vedenje o njih mogoče danes dopolniti z novim slovenskim in tudi drugim jezikovnim gradivom, kar praviloma omogoča bolj natančno kronologijo njihovega nastanka tudi v etimološkem pogledu.

Novi etimološki slovar slovenskega jezika (= NESSJ) je krovni naslov za temeljne etimološke raziskave slovenskega jezika, ki se v Etimološko-onomastični sekciji Inštituta za slovenski jezik Frana Ramovša ZRC SAZU izvajajo, odkar je bil dokončan prvi znanstveno zasnovan Etimološki slovar slovenskega jezika I-V (Ljubljana: Mladinska knjiga oz. Založba ZRC, 1976-2007) Franceta Bezlaja (ob njem sva bila avtorja gesel tudi Marko Snoj in Metka Furlan). Edina izvajalka teh del sem Metka Furlan. Trenutno kot obsežnejša naloga od druge polovice 2014. dalje vzporedno z izdelavo paberkovalno izbranih geselskih iztočnic za spletni rastoči etimološki slovar poteka obsežna sistemska obravnava slovenske zoonimske leksike, ki bo v rastoči slovar vključena, ko bo obravnava tega zajetnega tematskega sklopa, ki na sedanji delovni stopnji obsega okoli 7000 različnih slovenskih zoonimov iz knjižnih, narečnih in zgodovinskih virov, v celoti, tudi leksikografsko dokončana.

\section{GESELSIKI ČLANKI}

ardečina $\rightarrow$ ardičina

ESSJ Ø

ardičina

ESSJ Ø

ärdičîna interj za izražanje podkrepitve trditve, npr. ardičina! je vzkliknil (gor. - SSKJ), v enaki funkciji tudi ardečina; prvo varianto je uporabljal pisatelj Fran Saleški Finžgar (1871-1962), rojen v Doslovčah, prim. ardičina! je zaklel Jaka tako na glas, da se je Francelj spotaknil, drugo pa prevajalec Janko Moder (1914-2006), rojen v Dolu pri Ljubljani, prim. Viš ga, še eden. Ardečina! (Kartoteka SSKJ). 
Kletvici sta domači tvorjenki s sufiksom -ina $\mathrm{v}$ večalno-slabšalni funkciji (tip dekl-ina $\leftarrow$ dekle) iz nepotrjenih sln. kletvic *ardik in *ardek, ki sta prvotno pomenili *'preklet'.

Isln. *ardik in *ardek interj *'preklet'.

$\diamond \quad$ bav. avstr. *ardigg in *ardegg * "preklet'.

() Ker v bav. avstr. obstaja medmet/kletvica hardegg 'preklet' (WBÖ: I, 321), kar je lahko hipokoristik iz vzklika začudenja in blažje kletvice hardegāta (WBÖ: I, 321), in ker v bav. avstr. obstajajo tudi sinonimne variante $\mathrm{z}$ vokalnim in konzonantnim vzglasjem tipa ardegátta, hardigátta, je možno, da sta bav. avstr. *ardigg in *ardegg *'preklet', na katera kaže sln. gradivo, hipokoristika iz sicer neevidentiranega vzklika *ardigata, ki ga posredno potrjuje sln. ardigata ( $~$ ardigata), in potrjenega bav. avstr. ardegátta poleg hardegāta (Furlan, JZ 24/1, 2018, 135).

Ni verjetno, da bi bila sln. alternacija - $i-$ : - - - v razmerju ardičina $:$ ardečina posledica slovenske vokalne redukcije.

\section{- ardigata}

ärdigâta interj za izražanje podkrepitve trditve, npr. ardigata, pijača bi se prilegla! (dial. - SSKJ). Po Kartoteki SSKJ sta kletvico pisno uporabila pisatelj Ferdo Kozak (1894-1957), rojen v Ljubljani, in klasični filolog ter prevajalec Anton Sovre (1885-1963), rojen v Šavni Peči (v občini Hrastnik). K temu sin ardegata, ki je bil del besednega zaklada Lovra Kuharja (1893-1950), rojenega v Podgori pri Ravnah na Koroškem, in sin hardigata, ki je bil del besednega zaklada pisatelja Smiljana Samca (1912-1995), rojenega v Trstu, prim. Hardigata - sakramiš! S tabo je res velik križ: (Kartoteka SSKJ), sredi 60. let prejšnjega stoletja pa jo najdemo tudi v humorističnem časopisu Pavliha, prim. »Hardigata, kakšne debele svinje imate na Pobrežju! « sem pohvalil tamkajšnje svinjerejce, oni so se mi pa smejali: (Kartoteka SSKJ). Varianto ordigata je uporabljal pisatelj Matevž Hace (1910-1979), rojen v Podcerkvi v občini Loški potok, prim. Lepše je, da naša dva pri vojakih lenarita, kakor pa da bi se kje po nepotrebnem vojskovala, ordigata. (Kartoteka SSKJ).

Isln. *ardigata, *ardegata, *hardigata, *ordigata interj, vse v funkciji blažjih kletvic.

$\bullet \quad$ bav. avstr. *ardigátta, ardegátta, hardigátta, *ordigátta, vzklikov začudenja in blažjih kletvic.

Poleg bav. avstr. ardegátta in hardigátta, ki ju kot predlogi izposoje za sln. knjiž. ardigata po WBÖ: I, 321 navaja Reichmayr 2003: 186, obstajajo tudi sinonimne variante ardagatta, hartegatte, hardigatti, hardegāta (WBÖ l.c.), ki so bile iz izhodiščnega bav. avstr. *erdegatta *'preklet' kot 
madžarske izposojenke preoblikovane pod vplivom n. vzklika Herrgott! 'O, moj bog!' itd. (WBÖ 1.c.), dial. hargot 'isto' (Schatz 1955: 290) in drugih dejavnikov, kot so bav. avstr. pari tipa gärtner/gartner, labializirane variante tipa gertner, hipokoristik hardegg 'preklet' idr. (Furlan, JZ 24/1, 2018, 132ss.).

() Izvorno madž. *erdegadta $\Leftrightarrow$ hrv. kajk. erdegata interj 'kletvica za izražanje nerazpoloženja, jeze, neprijetnega presenečenja' - RHKKJ), po labializaciji sodobno madž. ördögadta (z ördög 'hudič'), je ptc pret v pomenu *‘od hudiča dan', tj. 'preklet' (Reichmayr l.c.; Furlan 1.c.).

(D) BD

Bav. avstr. *erdegatta ( $\hookleftarrow$ madž. *erdegadta *'preklet’, sodobno ördögadta)

$\rightarrow$ PO RAZLIČNIH VPLIVIH (Herrgott!/hargot!; gärtner/gartner/gortner itd.)

bav. avstr. hårdigotti, hardigatti, ardagatta, ardegátta, hartegatte, hardegāta $\rightarrow$ HIPOKORISTIK hardegg

*ardegg $\Rightarrow$ sln.*ardek;

$\rightarrow$ IZPELJAVA -ina $\sin$. ardečina;

*ardigg $\Rightarrow$ sln. *ardik

$\rightarrow$ IZPELJAVA -ina sln. ardičina;

hardigatta $\Rightarrow$ sln. hardigata;

$\rightarrow \times$ mejduš sln. harduš;

$\rightarrow \times$ mejdun sln. hardun;

*ardigatta $\Rightarrow$ sln. ardigata;

$$
\rightarrow \times \text { mejdus }
$$
sln. arduš;

$\rightarrow \times$ mejdun sln. ardun;

ardegátta $\Rightarrow$
sln. ardegata; * ordigatta $\Rightarrow$ sln. ordigata.

$\Rightarrow$ ardečina $\Rightarrow$ ardičina $\Rightarrow$ ardegata $\Rightarrow$ hardigata $\Rightarrow$ harduš $\Rightarrow$ hardun $\Rightarrow$ arduš $\Rightarrow$ ardun

ärdûn interj za izražanje podkrepitve trditve, npr. dobro smo jih, ardun (pog. - SSKJ).

(E) Nastalo po križanju med kletvicama ärdigâta, ki izraža podkrepitev trditve (SSKJ), in mëjdûn/mệjdūn, ki izražata podkrepitev trditve (SSKJ): ardigata $\times$ mejun $\rightarrow$ ardun (Furlan, JZ 24/1, 2018, 133).

\section{- prmejdun - ardigata}

\section{arduš}

ESSJ Ø

ärdūš interj za izražanje močne podkrepitve, npr. arduš, sem se ustrašil (pog. - SSKJ); v narečjih: štaj. zgsav. 'a:r'duš je kletvica, ki izraža podkrepitev trditve (Zadrečka dolina - Weiss 1998), dol. arduš izraža močno podkrepitev trditve (Suha krajina - A. Legan Ravnikar, ustno). Kletvico najdemo 
pri piscih 20. st. (Kartoteka SSKJ), npr. Nič drugega ni rekel, kakor svojo običajno kletev »arduš" je izustil, potem se je pa naglo oblekel ... (SN 26. 5., 1909, XLII/118, 1; vir: dLib.si), in v virih pred 20. st. ni bila zapisana, niti v Pleteršnikovem slovarju ne.

(E) Kletvica je posledica križanja med kletvicama ärdigâta, ki izraža podkrepitev trditve (SSKJ), in mëjdûš/mệjdūš, ki izraža močno podkrepitev trditve (SSKJ): ardigata $\times$ mejduš $\rightarrow$ arduš (Furlan, JZ 24/1, 2018, 133).

\section{- prmejduš - ardigata}

blede

ESSJ s.v. pệsa

$b^{\prime}$ lede $\mathrm{f}$ pl 'blitva = Beta vulgaris' (primor. - Kartoteka SSKJ); v narečjih: istr. b'lede f pl 'blitva, Beta vulgaris' (Boršt (Istra) - Giljanović Diss. 2011: 379), nad. blèda f 'isto' (Špehonja 201212), blèda (Rigoni-Salvino 1999 s.v. bietola), ter. blóda (Spinozzi Monai 2009: 347), briš. bleda (Korenjak 2012), bovš. bleda (Benko - Špolad Žuber 2008: 191).

IsIn. $\mathrm{ftn} * b^{\prime} l e: d a \mathrm{f}$ 'Beta vulgaris', navadno rabljeno pluralno (zahodno).

$\diamond \quad$ po dvojni poti. Medtem ko je bil nad., ter., briš. in bovš. ftn izposojen iz furl. blède f 'blitva' (NP), je bil istrski izposojen iz it. ben. predloge bleda 'Beta vulgaris', ki je bila evidentirana v Trstu, Miljah in Gradežu (Rosamani 1990; Doria 1987; Bottin 2003) in v drugih sln. in hrv. istrskih krajih, kjer se še govori istrobeneščina, in sicer v Kopru bléda (Manzini-Rocchi 1995), Izoli blèda (Sau 2009), Hrvatinih b'lede (Todorović 2017: 196), Momjanu bleda (Filipi - Buršić Giudici 2012: 899), prim. tudi biz. bleda (VFDB). Na tem območju je leksem lahko ostanek istrsko-romanskega substrata, toda v slovenskem delu Istre tudi uporabljano sinonimno sln. b'liẹdàs (Škofije), $b^{\prime} l i a d \partial s$ (Dekani; oboje Todorović 2017: 196; S. Todorović, ustno), b'liadàs (Sveti Anton; Todorović 2018: 219) <*b'le:de-s in b'lẹdăš (Puče; Todorović 1.c.), b'ledeš (Padna; Todorović - Koštiál 2014: 134), bledeš (Pucer 2000: 207) s konzonantnim izglasjem kaže na izposojo iz furl. predloge v pluralni obliki blèdes, pri čemer je sln. izglasni -̌s (ob -s) mogoče razložiti z it. ben. posredovanjem. Obe varianti sta bili v sln. sekundarno singularizirani. Varianta $b^{\prime} l e-$ deš (Padna) se verjetno pod vplivom sln. subst na -ež hiperkorigirana pojavlja v hrematonimu Praznik olja in bledeža (Padna).

Rom. * $b^{\prime} l e: d a$ 'Beta vulgaris' (prim. brez lenizacije it. tosk. bièta 'isto' (16. st. - Battisti-Alessio: 514)) < lat. blēta (5. st. - Rocchi 1990: 74).

() Lat. blèta 'Beta vulgaris' je nastalo s križanjem med lat. sin bēta 'pesa' ( - pesa) in blitum 'vrsta špinače' (Battisti-Alessio 1.c.; Rocchi 1.c.). Manj verjetno Skok: I, 164, ki je domneval, da se je ftn fonetično razvil iz dem * bètula > *bètla, po premetu lat. blèta.

\section{- blitva}


bledě̌ $\rightarrow$ blede

ESSJ Ø

bonifika

ESSJ Ø

bonifika f 'prekop, izsuševalni kanal' (briš. - Erzetič 2007).

(a) Ničto onimizirano v mtpn Bonifika f 'meliorirani predel Kopra med mestnim jedrom in Semedelo'.

Isln. *bo'ni:fika 'izsuševanje močvirnatih tal', sekundarno 'izsuševalni kanal' (zahodno); kulturna izposojenka.

$\diamond \quad$ it. bonifica 'izsuševanje močvirnatih tal, melioracija; meliorirano zemljišče'.

(E) It. bonifica 'izsuševanje močvirnatih tal, melioracija; meliorirano zemljišče' je deverb od bonificare 'meliorirati, izsuševati', $b$. una palude 'izsušiti močvirje'. Zadnji vir je srlat. bonificāre 'delati boljše = izboljševati' (leta $1289) \leftarrow$ lat. bonum facere ‘delati dobro’ (Battisti-Alessio: 559s.).

Sln. knjiž. bonificîrati -am impf/pf 'izboljšati tla', npr. bonificirati izsušeno močvirje (SSKJ), je zaradi izglasja -icirati izposojeno prek n. bonifizieren 'izboljšati'.

bregniti $\rightarrow$ brezeti

ESSJ Ø

\section{breza $^{1}$}

ESSJ brẹza

brẹ́za f 'Betula' (SSKJ; Pleteršnik); v narečjih: kor. obir. brézza (Karničar 1990), nad. brìeza (Špehonja 20121), cerklj. b'ri:za (Kenda-Jež Diss. 2002: *21), briza (Razpet 2006), tolm. ந́ri:aza (Čujec Stres 2010), črnovr. brîaza (Tominec 1964), gor. bré:za (Kropa - Škofic Diss. 1996: 278), štaj. zgsav. b'ré:za (Zadrečka dolina - Weiss 1998), pkm. b'rẹ:za (Gornji Senik - Bajzek Lukač 2009), prleš. b'rẹza (Rajh 2010).

† Kol brệzje n 'brezov gozd' (SSKJ; Pleteršnik), kor. obir. brè:zje 'isto' (Karničar 1990), brîzie (Podklošter/Arnoldstein - SLA), nad. brìezje (Špehonja 20121), tolm. ந'ri:azja 'brezovo vejevje; skupina brez' (Čujec Stres 2010), cerklj. b'ri:zje 'brezov gozd; brezovo šibje' (Kenda-Jež Diss. 2002: *21), prleš. brệzję (Miklavž pri Ormožu - SLA), b'rẹ:zje 'skupina brez, brezov gozd' (Rajh 2010); kol bre'zi:je n 'brezovo vejevje' (prleš. - Rajh 2010) < *bre'zi:nje; kol brẹzovje n 'brezov gozd' (SSKJ; Pleteršnik); dem brẹzica (Pleteršnik), štaj. zgsav. b'ré:zęa (Zadrečka dolina - Weiss 1998) < *brẹzika; bkr. brézik m 'brezova hosta, brezje' (Šašelj 1906); denom adj brẹzov, f - a (SSKJ; Pleteršnik), kor. obir. bré:zu (lè:s) 'brezov les’ (Karničar 1990), tolm. ந'ri:azou, f -awa (Čujec Stres 2010), črnovr. brîzawa mệtta (Tominec 1964), cerklj. b'ri:zau, f b'ri:zawa (Kenda-Jež Diss. 2002: *22), štaj. zgsav. b'ré:zo, f -va (Zadrečka dolina - Weiss 1998), pkm. b'rẹ:zove (Gornji Senik Bajzek Lukač 2009); subst cerklj. b'ri:zauc m 'brezova šiba za poganjanje volov' (Kenda-Jež Diss. 2002: *22), brízauc 'brezovec, naprava za tepež' (Razpet 2006), štaj. zgsav. b'ré:zoc 'bič, spleten iz brezovih šib' (Zadrečka 
dolina - Weiss 1998), prleš. b'rẹzofca 'brezova metla', b'rẹzovina 'brezov les', b'rẹovjak 'brezov gaj/gozd' (Rajh 2010) (<*brẹ́zovnjak); denom adj brẹ́zast 'tak, ki je podoben brezi' (Pleteršnik). (T) 17. st.: breśsu 'betuleus', bréfovje 'betuletum' (Kastelec-Vorenc); 18. st.: brefje 'Birkenreihe, betuletum', bre fov 'von Birken, betuleus', brefovina 'Birkenholz, betulea ligna' (Pohlin); bresje, briesje 'Birkenwald', bresou, bresen 'Birken-', bresou liefs 'Birkenholz', bresou mozhnik 'Prügelsuppe, tepenje, pretep, otepenje', bresovina 'Birkenholz', 'Birkenwald' (Gutsman).

(1) 16. st.: brefa 'Birckenbaum, betula' (Megiser 1592); 17. st.: bréfa 'betula' (Kastelec-Vorenc); 18. st.: brefa 'Birkenbaum, betula' (Pohlin), bresa 'Birke' (Gutsman).

(O) Ftn brẹ́za je z izpeljankami pogosta tpn osnova, a slovenščina češkega tpn tipa Lipá ne potrjuje (Bezlaj 2003: 163), ampak so tpn tipa Bréza onimizirana prek kol funkcije tipa r. on lovil rybu 'lovil je ribe' (Bezlaj 1.c.). O tem podrobneje Bezlaj 1956-1961: I, 86; isti ESSJ: 43; isti 2003: 165, 203; Merkù 2006: 51; Šekli 2008: 72; Snoj 2009: 79s. Pri identifikaciji izvora homonimnih tpn tipa Brezno in Brezen ( $\leftarrow \operatorname{sln}$. brẹ́za f 'Betula' ali brézno n 'prepad') bi bilo treba upoštevati tudi dejstvo, da v slov. svetu ftn ni vedno ap A (glej spodaj). Psln. ftn *brĕ̃za f 'Betula' (splošno).

- = hrv. brjëza 'Betula', srb. brèza 'isto', v Vojvodini bréza z dem brézica (RSGV), mak. breza, blg. brezà (BER: I, 76), r. berëza, ukr. beréza, br. bjaróza, č. bř́za, slš. breza, p. brzoza, dl. brjaza, gl. brěza;

< psl. ftn *bërza f (ap A)/*berzä f (blg.) 'Betula' poleg *bërzъ m (ap A) 'Betula' ( - brez $\left.{ }^{2}\right)$;

- = let. bẹrrza 'breza', stnord. bjork 'isto', stagl. berc; psl. *bërzъ = lit. béržas 'breza', let. bẹrzs 'isto' in stpr. berse (Furlan, SR 56/2, 2008, 9);

$<$ pide. dial. ftn * $b^{h} e ́ r g ' H_{1} e H_{2}$ in * $b^{h} e ́ r g ' H_{1} o-s$, oboje 'Betula'; sorodno je tudi sti. bhürjá- m 'vrsta breze', stvn. birka 'breza' (9. st.), birihha 'isto’ (11. st.; s sekundarnim drugim - $i$ - iz pgerm *berkjō), srvn. birke, birche, nvn. Birke, stagl. birce, agl. birch in verjetno tudi lat. fraxinus m 'jêsen' $\left(<* b_{r}^{h_{r}} H_{l} g\right.$ '-s-el ino-s) s prenosom na označevanje jesena, ker v južni Evropi (bela) breza ni avtohtona (Walde-Hofmann ${ }^{3}$ : I, 544; de Vaan 2008: 240s.).

() Ker se dendronim, ki brezo poimenuje po značilni (bleščeče) beli barvi lubja, upravičeno povezuje s sti. bhrájate 'blesteti, sijati', aor ábhrāt 'je zasijal', bhrấj- f 'blesk', bhrājá- adj 'žareč, svetlikajoč se', mav. brāzaiti 'sijati', brāz- 'blesk' s pide. aor korenom *bhreH $g^{g}$ - 'zasijati, zablesteti' (LIV2: 92), je razmerje med ničtostopenjskimi tvorbami tipa sti. bhürjá- in polnostopenjskimi tipa psl. *bërza mogoče razložiti z aplikacijo lebdečega prevoja (n. Schwebeablaut) kot posledico besedotvornega vzorca; dendronimsko izhodišče je verjetno izsamostalniški adj $* b_{r}^{h_{r}} H_{1} g$ '-ó- 'bleščeč, sijoč = bel' iz korenskega subst ${ }^{*} b^{h} r e ́ H_{1} g^{\prime}-=$ sti. bhráj- 'blesk' (tipa sti. usr-á'jutranji, rdečkast' $\leftarrow$ uṣar-f ' jutranja zarja'), ki ga potrjuje alb. bardhë 'bel' 
in se ničto substantiviziran ohranja v sti. bhürjá-, drugod pa je bil korenski

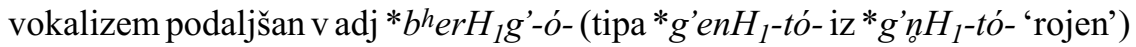
in $\mathrm{z}$ akc umikom tako kot adj $* g$ 'en $H_{1}$-tó- $\rightarrow * g$ 'én $H_{l^{-}}$to- $=$pgerm. $* k i n P a-=$ stvn. kind, nvn. Kind substantiviziran v *b'érH $H_{1}$ ' $-o-s \mathrm{~m}$ 'breza' $=$ psl. *bërzъ

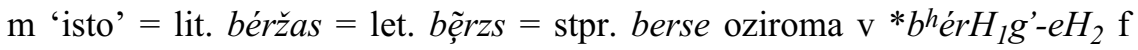
'breza' = psl. *bërza 'isto' = let. bẹrrza = stnord. bjork = stagl. berc; zaradi akc drugačnega psl. dial. *berzä f 'Betula' (blg.) je treba predpostaviti, da je bila adjektivna predloga tudi ničto substantivizirana (podrobno Furlan o.c., 9-13; podobno že J. Schindler pri Mayrhofer: II, 270). Izvajanje dendronimov iz korenskega subst amfikinetičnega tipa $* b^{h} e ́ r H_{1} g^{\prime}-s / b^{h} H_{o} H_{l} g^{\prime}-e ́ s$ (Darms 1978: 428s. s starejšo literaturo; ERHJ: I, 83) v okviru konsenzualno sprejete povezave s pide. korenom $* b^{h} r e H_{1} g$ '- 'zasijati, zablesteti' (Berneker: 52; Bezlaj ESSJ: I, 43; Skok: I, 207; Mayrhofer 1.c.; Derksen 2008: 38) lebdečega prevoja ne pojasnuje.

Iz psl. ftn *bërza/berzä f 'Betula' oz. *bërzb m 'isto' je bil po vzorcu tipa psl. *gölqbb m 'columba' $\rightarrow$ adj *gölqbr 'tak, ki je barve goloba' v r. golubój 'nebesno moder', ukr. holubýj 'moder' (Miklošič 1875: 51) tvorjen adj *bërzb 'barve breze $=\mathrm{z}$ belimi lisami (kot breza)' (Furlan, Miklosichiana 2013: 252s.) in ne obratno, kot se domneva v SP: 1, 212; ÈSSJa: I, 207s., 203, saj bi psl. refleks pide. adj * $b^{h} e r H_{l} g^{\prime}$-ó- spadal v ap C in ne A, kot kaže gradivo ( - breza $\left.^{2}\right)$.

(D) BD

Pide. adj * $b^{h} r e H_{l} g^{\prime}$-ó- (= sti. bhrājá- adj 'žareč, svetlikajoč se'):

$\rightarrow$ psl. denom *brězễti *'svetlikati se, žareti' (?) > sln. brezeti 'daniti se';

pide. dial. ftn * bhér $H_{1}$ g'-o-s/-eH 'Betula' (= lit. béržas = let. bệrzs = stpr. berse/let. bẹrrza = stnord. bjork; prim. še sti. bhürjá- m 'vrsta breze'):

= psl. ftn *bërzb/bërza 'Betula'

$>$ sln. brezal 'Betula';

$>$ sln. brez' 'Betula';

$\rightarrow($ ?) *bërzbn'a

$>$ sln. briznja 'Betula';

$\rightarrow$ denom adj *bérzb 'barve breze $=\mathrm{z}$ belimi lisami (kot breza)':

*bërzaja körua

$>$ sln. breza $^{2}$ 'lisasta krava';

$\rightarrow$ denom subst *bërzbcb

$>$ sln. brezec 'progast vol';

$\rightarrow$ denom adj *bërzbns 'Betulae'

$>$ sln. brezni petelin 'ruševec';

$\rightarrow$ subst * bërzbnb

$>$ sln. brezen 'marec';

$\rightarrow$ subst * bërzbnica

$>$ sln. breznica 'vrsta hruške ...';

$\rightarrow$ adj *bërzastb 'tak kot breza $=$ belolisast'

$>$ sln. brezast 1 'lisast';

$\rightarrow \sin$. brezast $\boldsymbol{t}^{2}$ 'umazan'.

$\Rightarrow$ brezeti $\Rightarrow$ brez $^{2} \Rightarrow$ breza $^{2} \Rightarrow$ brezec $\Rightarrow$ brezni petelin $\Rightarrow$ brezen $^{1} \Rightarrow$ breznica $\Rightarrow$ brezast $^{1}$ $\Rightarrow$ brezast $^{2} \Rightarrow$ briznja 
brẹ́zast adj, f - $a$ 'lisast, marogast' (SSKJ), brẹ́zast 'lisast, marogast (o govedi in kozah)' (Pleteršnik); v narečjih: tolm. ந́'ri:azast 'z belimi lisami' (Čujec Stres 2010).

$\boxplus$ 16. st.: bresafte, pirhafte inu piffane (Dalmatin 1584); 18. st.: brefaft 'gestreift, striatus' (Pohlin), bresaft 'buntfleckig, buntscheckicht, lezhen, lezhaft, pikaft, Jharovit', 'scheckicht, pikaft, vprishan, Jhekaft', 'gestreift' (Gutsman). IsIn. *brẹ́zast adj *'tak, ki je kot breza, z belimi lisami, marogast, progast'. () Ker je za brezo značilno belolisasto lubje, je bil adj na -ast izpeljan neposredno iz sln. ftn brẹ́za f 'Betula'.

- breza $^{1}$

\section{brezast $^{2}$}

ESSJ Ø

brẹ́zast adj, f - $a$ 'po obrazu umazan' (tolm. (Temljine) - Kenda 1926). V isto pomensko polje spada tudi tolm. brẹ́zec m, g -zca 'po obrazu umazan človek' (Temljine - Kenda 1.c.).

() Verjetno po internem sln. dial. pomenskem razvoju 'lisast, marogast' $\rightarrow$ 'umazan' nastalo iz sln. homon brẹ́zast adj 'lisast, marogast (o govedi in kozah)' ( $\sim$ brezast $\left.^{1}\right)$, izpeljanke iz sln. ftn brẹ́za f 'Betula'.

- brezast ${ }^{1}$

brezdeti $\rightarrow$ brezeti

ESSJ s.v. brệsk

brezec

ESSJ $\emptyset$

brệzec m, g -zca 'progast vol' (Lašče - Pleteršnik), 'progast pisan konj' (Pleteršnik); v narečjih: brẹ́zec m, g -zca 'po obrazu umazan človek' (tolm. (Temljine) - Kenda 1926).

(2) Verjetno ničto onimizirano v cgn Brezec kot bivšem vzdevku za umazanega človeka, čeprav zaradi sln. sufiksa $-e c<*_{-b c b}$ za tvorbo prebivalskih imen ne gre povsem izključiti možnosti, da je cgn tvorjenka iz sln. tpn Brẹza. Isln. dial. *brézzac m 'kdor je progast' $\rightarrow$ 'kdor je umazan'.

() Gradivo kaže na sln. dial. pomenski razvoj 'lisast, progast' $\rightarrow$ 'umazan' izpeljanke *brẹzzac *'tak kot breza' iz sln. ftn brẹ́za f 'Betula'.

- breza $^{1}$

brezen $^{2}$

ESSJ s.v. brẹ́ziti se

brezen m, g -zna 'parjenje mačk' (Pleteršnik po Cafu), brezen 'Brunft' (Cigale 1860); v narečjih: rovt. polj. brézn 'pojatev živine' (Škrlep 1999).

(1) Denom brẹznati se brệznam se impf 'kazati nagnjenje za parjenje, goniti se (navadno o mačkah)' (SSKJ), brẹ́znati se -am se impf 'goniti se (o mačkah)' (Pleteršnik po Cigaletu 1860 s.v. brunften, Cafu, Miklošiču in z oznako, da je glagol znan na Krasu), tudi 'klatiti se' (Pleteršnik po Cafu), 
črnovr. brîzznat sẹ ‘pariti se (o mačkah)' (Tominec 1964), cerklj. bríznat se 'goniti se', npr. Náša muca se furt na fúrt brízna (Razpet 2006) 'Naša mačka se neprestano goni', b'ri:znat se 'pojati se (spomladi o mačkah)', tudi 'potikati se' (Kenda-Jež Diss. 2002: *22), bovš. bərzná:te -à:m 'preganjati se, divjati, loviti se' (Ivančič Kutin 2007); deverb nomen actionis bríznajne 'mačje gonjenje, parjenje', npr. Patle se j pa uníelu uakúl bajte anu strašnu cuilejne, pihajne mpa bríznajne (cerklj. - Razpet 2006) 'Potem pa se je okoli hiše začelo strašno cviljenje, pihanje in breznanje', polj. bréznajne 'mačje parjenje; nemoralno spolno občevanje ali mladostno razgrajanje' (Škrlep 1999).

Isln. dial. *b're:zən m 'parjenje mačk' (zahodno).

() Ker le na zahodnem sln. območju potrjena besedna družina nima pomenskih ustreznic $\mathrm{v}$ drugih slov. jezikih in ker ob pozno izpričanem glagolu brẹ́ziti se -im se impf 'goniti se (o mačkah)' (Pleteršnik po Cigaletu 1860 s.v. brunften (von Katzen): breziti se in Janežiču 1893: breziti se -im se 'Brunften (v. Katzen)') obstaja tudi glagol brestiti se -im se = briš. bri'astat se 'pariti se (o živalih)' (Erzetič 2007), prim. mačke se brestijo 'mačke se gonijo' (bkr. Pleteršnik), kar je fonetična varianta k mrestíti se -ím se 'pariti se (o gadih, divjih petelinih, jelenih)' (Pleteršnik), je možno, da se je na podlagi sln. korenske homonimije med ftn brẹst $\mathrm{m}$ 'Ulmus' in glagola brestiti se 'pariti se (o živalih)' ustvarila ljudskoetimološka povezava, ki je povzročila, da se je podobno razmerje realiziralo tudi pri ftn brẹ́za f 'Betula' in nastal je neologistični denom brẹziti se 'goniti se', novi pomen pa se je prenesel tudi na subst brẹ́zen m, g -zna 'marec; april', ker se v spomladanskih mesecih živali parijo. Formalno in pomensko izhodišče te sln. po analogiji nastale besedne družine je denom brẹziti se 'goniti se', zato ni povsem prepričljiva domneva Bezlaja ESSJ: I, 43, da naj bi se pomenski premik realiziral šele v subst brẹ́zen $\mathrm{m}$, g -zna 'marec; april' $\rightarrow$ 'pojanje mačk'. Ker p. marcować się 'goniti se' (S. Torkar, ustno), dial. tudi marczyć się 'isto' (Karłowicz SGP) kot denom iz marzec 'marec' (in ne tudi 'gonjenje, pojanje') kaže, da bi se pomen 'goniti se' v sln. brẹ́znati se lahko razvil tudi, če bi bil denom iz brẹ́zen m 'marec; april', sta na nastanek te sln. dial. besedne družine lahko vplivala dva dejavnika, tj. denom brẹ́znati se $\longleftarrow$ brẹ́zen $\mathrm{m}$ 'marec; april' in razmerje brẹst $\mathrm{m}$ 'Ulmus' : brestíti se 'pariti se (o živalih)' $\rightarrow$ brẹ́za $\mathrm{f}$ 'Betula' $: \mathrm{x}=$ brẹziti se 'goniti se (o mačkah)'.

\section{- brestiti se}

\section{brezeti} ESSJ s.v. brệsk

brezẹti -í impf 'daniti se’, npr. solnce za goro brezi (dol. - Pleteršnik po Miklošiču 1886: 21).

Psln. *brězëti (?).

$<$ psl. dial. *brězĕ́ti (?). 
() Glagol je s sin brezdẹti -í impf 'daniti se' (dol. - Pleteršnik po Miklošiču 1.c.) gotovo soroden s psl. *brězgb m 'jutranji svit, zora' = str. brězgb 'diluculum' in psl. sin *brěsks $\mathrm{m}=\mathrm{s} \ln$. brệsk m 'jutranji svit' ter nadalje s psl. ftn *bërza f 'Betula' = sln. brẹ́za 'isto’ (Miklošič l.c.; Berneker: 85; Bezlaj ESSJ: I, 42; Skok: I, 207). Ker se v njih ohranja pide. koren s prvot-

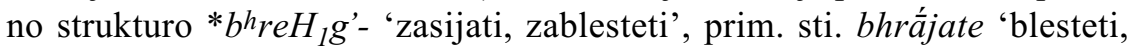
sijati', bhrấj- f 'blesk', bhrājá- adj 'žareč, svetlikajoč se', mav. brāzaiti 'sijati', brāz- 'blesk' (Miklošič 1.c.; LIV2: 92; Mayrhofer: II, 279s.), ki bi se realiziral kot psl. *brěz-, je možno, da je sln. brezẹti arhaični ostanek denom glagola, ki je bil zaradi akcentskih razmer bolj verjetno kot iz korenskega subst, ki se ohranja v sti. in av., tvorjen iz adj predloge, ki jo potrjuje sti. bhrājá-; sln. varianta brezdẹti tako kot psl. *brězgati 'svitati se' (= stp. brzazgać 'dilucescere', slš. dial. brizgac 'daniti se' - SP: 1, 375), sekundarno *brěskati, lahko izvira iz obdobja nastajanja fonetičnih variant tipa *bzrzb 'hiter' : *bbrzdb 'isto': *bbrzgz; *bzzb m 'Sambucus' : *bbzdb 'isto' : *bzzgz (o slednjih Šivic-Dular, Zb Bezlaj 2012: 231ss.) iz prvotnih tipa *bъrzъ : *bъrgъ (Miklošič o.c.: 11), ki so zaradi lit. burzdùs : burzgùs (oboje 'hiter') starejše od praslovanščine. Miklošičeva domneva o dvojnih, satemskih in kentumskih refleksih v slov., se potrjuje tudi v tej besedni družini, saj sln. ohranja tudi kentumsko varianto pide. korena * bhreH ${ }_{1}$ '- v brẹ́gniti brệgnem pf 'zasijati', npr. solnce bregne skozi oblake, obrẹ́gniti se obrệgnem se 'zjasniti se', npr. nebo se je obregnilo (oboje Pleteršnik po Trstenjaku), kot je opozoril že Bezlaj v ESSJ PZ 1963: 10 in opustil v ESSJ.

Obstoja č. brezditi se 'daniti se', ki ga omenja Skok 1.c., drugi viri ne potrjujejo, ampak Jungmann navaja le č. bř́žiti se -ím se 'daniti se', kar je verjetno denom od *brězgz m 'jutranji svit, zora'.

- bresk - breza1

breziti se $\rightarrow$ brezen $^{2}$

ESSJ brẹziti se

\section{breznica}

ESSJ Ø

brệznica f 'vrsta hruške; vrsta jabolka' (Pleteršnik po Cafu); v narečjih: štaj. zgsav. b'ré:zənca f 'okrogla, srednje debela hruška, zrela v začetku julija' s sin dobrica (Zadrečka dolina - Weiss 1998), pkm. b're:iznece f pl 'vrsta sliv' (Gornji Senik - Bajzek Lukač 2009).

Isln. dial. *brệznica $\mathrm{f}(<$ psln. *brẽznica $<$ psl. *bërzbnica).

() Nejasno.

Izvajanje iz sln. brẹ́zen m, g -zna 'marec', 'april', kar bi impliciralo, da so sadeži poimenovani po času zorenja, ne pride v poštev, ker jabolka in hruške $\mathrm{v}$ teh mesecih ne zorijo. Morda gre za prvotno poimenovanje sadežev $\mathrm{z}$ značilnimi svetlimi/belimi lisami, ki so asociirali na brezovo lubje, in je treba 
izhajati iz subst *bërz-bn-ica, ki je bil prek adj *bërz-bnъ tvorjen iz ftn brẹ́za f 'Betula' < psl. *bërza 'isto'.

- breza $^{1}$

\section{briznja $E S S J \emptyset$}

brîzńa f 'breza', tudi brîzńä ‘isto’ (primor. rez. (Osojane/Oseacco) - SLA).

Psln. dial. ftn *brězn'a 'breza' (zahodno).

$<$ psl. dial. *bërzbn'a 'breza'.

(E) Nejasno.

V odnosu do splošno slov. *bërza 'breza' v besedotvornem oziru osamljena in nejasna tvorba. Tvorjenke tipa *golua $\rightarrow$ *golu-bn'a (SP: 1, 138) praviloma s svojo besedotvorno podstavo niso sinonimne. Zaradi rez. $-\hat{\imath}$ - kot odraza novocirkumflektiranega jata in zaradi $-n-n$ ni mogoče predpostaviti, da bi bil leksem fonetično razvit iz psl. *bërzina v funkciji singulativa, kot je npr. hrv. brëzina 'breza'.

$\mathrm{V}$ formalnem razmerju med genitivom splošno sln. dëž m, g dežjä 'pluvia' in rez. də̄š, g dažnjṕ je rezijanski -n-v stranskih sklonih rezultat zgodnje disimilacije $d: d$ ' $\rightarrow d: n^{\prime}$ (Ramovš 1935: 33), ki je pri razlagi nastanka rez. brîzńa ni mogoče aplicirati.

\section{- breza ${ }^{1}$}

bröč $\mathrm{m}, \mathrm{g}$ brọ́ča 'rastlina z rdečim barvilom v koreniki' (dial. - SSKJ) = 'Rubia tinctorum', brôč ‘Krapp (rubia tinctorum)' (Pleteršnik), broč 'Krapp' (Cigale 1880).

(T) Denom adj brọ́čev, f - $a$ (SSKJ); denom brọ́čiti brộčim impf 'rdeče barvati', npr. bročiti pirhe 'rdeče barvati pirhe' (gor. - SSKJ), brọ́čiti -im 'rdeče barvati', npr. bročiti jajca, s krvjo bročiti (Pleteršnik), Sedeval sem tam gori, kadar je jutranja zarja bročila velikanovo teme (Mencinger, Moja hoja na Triglav, 1897), gor. brọ́čat brọ:č̀m 'barvati pirhe' (Kropa - Škofic Diss. 1996: 278 z oznako starinski); deverb bročivo 'Krapproth' (Pleteršnik; Cigale 1880); bRočt:lka 'rdeča barva za pirhe' (Kropa - Škofic Diss. 1996: 278 z oznako starinski).

Psln. *bröć m 'Rubia tinctorum'.

- = csl. broštb m 'purpura', hrv. bröć, g bròća 'Rubia tinctorum', 'rdeča barva za barvanje pirhov' (Vodice), brôć m, g broćà 'Rubia tinctorum, Krapp, Farbenröthe' (ČDL), leta 1670 brouch 'Rubia' (Habdelić), srb. bröć, bròća 'rastlina z rdečim korenom, ki se uporablja za barvanje jajc', tudi bròci$k a$ 'Rubia tinctorum' (Vojvodina - RSGV), mak. brok' 'isto' (TRMJ), blg. brošt in po sekundarni dial. pridobitvi zvena brožd ter broč, dial. refleksa iz prvotnega brošt (BER: 1, 81, 80), ukr. brič, g bročá 'Genista tinctoria' (Grinčenko), brič ‘Rubia tinctorum', broča 'isto', brošč (Makowiecki 1936: 
317), p. brocz 'rdeča tekočina, rdeč sok', dial. 'Rubia tinctorum', kar je najverjetneje izposojeno iz ukr. (Jokl, Zb Jagić 1908: 485; Boryś 2005: 39), stč. brotec 'isto', nč. zbrotiti 'omadeževati', z. krví 'okrvaviti', broc 'Rubia tinctorum', brot 'isto', brotec, brotno (Rystonová 2007: 341), toda stcsl. broštenz 'rdeče pobarvan', obroštenb ‘isto' kot ptc denom glagola *brotiti ali *brot'iti;

< psl. *bròt'b m (ap B) 'Rubia tinctorum' (in zaradi denom *brotiti najbolj verjetno tudi *brotb $\mathrm{m}$ 'isto').

$\diamond \quad$ lat. bractea 'škrlat' in ne iz brattea 'isto' $(\Leftrightarrow$ slov. **bročb) s primarnim pomenom 'zlata ploščica' (Jokl l.c.; Walde-Hofmann ${ }^{3}$ : I, 109; Vasmer: I, 220s.; Machek 1968: 68; Skok: I, 215; ÈSSJa: 3, 40s.); pomen 'škrlat' je v besedi posledica vpliva lat. blatta 'kaplja krvi, škrlat' (Walde-Hofmann 1.c.).

Ker slov. tvorjenk z osnovo *brot- ni mogoče tako kot jslov. tipa sln. brošč ( $>$ *brot'bcb) razložiti z interno slov. fonetiko, je možno, da je ob lat. bractea, brattea 'škrlat' obstajala tudi sinonimna varianta *bratta (prim. lat. blatta 'kaplja krvi, škrlat'), ki je bila v psl. izposojena kot *brotb.

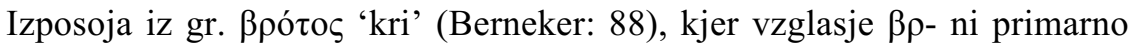
grško, je tudi zaradi večinskega izglasja psl. *brot'b manj verjetna.

R. brusk 'Rubia tinctorum' s tem psl. latinizmom ni v nobeni povezavi, ampak spada v besedno družino r. brúska 'brusnica' (Vasmer l.c.; Anikin: 4, 278s.). Romun. bro'chŭu, bro'č̆u 'Rubia tinctorum' je bilo izposojeno iz ukr. (Miklošič 1886: 22) ali iz srb. (Tiktin: I, 225).

(D) ${ }^{B D}$

Lat. bractea 'škrlat' (brattea 'isto'):

$\Rightarrow$ psl. *bròt'b m 'škrlat' $\rightarrow$ 'Rubia tinctorum' $>\quad s \ln$ broč; jslov. *brot'bcb 'Rubia tinctorum' $\quad>\quad \sin$. brošč.

$\Rightarrow$ brošč

\section{brzen $^{2}$}

ESSJ S.v. briz

bŕzen adj, f -zna 'ljubek, zelo čeden' (kor. - Pleteršnik po Cafu), npr. brzno dekle (Pleteršnik po Cafu), brzen gospod (zilj. - Pleteršnik), adv brzno (poje zvon) (Pleteršnik po Cafu) 'lepo (poje zvon)'; v narečjih: kor. rož. bŕzən adj, f -zna 'fleten, prijeten, čeden' (Šašel 1957), pkm. br̀zen adj, f -zna 'brhek' poleg 'hiter' (Beltinci - Novak 1996).

$\boxplus$ 18. st.: bersen 'staatlich, priden, Jhteifen, sal, berhki, hud' poleg bresen 'trefflich, gofpoda/hen, sal, hud, priden' (Gutsman).

Psln. *brzan adj 'izvrsten, izreden ...' (severno).

< psl. dial. *bzrzbnz 'izvrsten, izreden ...' $\leftarrow$ 'hiter'.

() Bezlaj ESSJ: I, 50 je sklepal na pomenski razvoj v okviru besedne družine $b \hat{r} z$ adj 'hiter' < psl. *b̂ิrzb 'isto', sln. dial. bŕzen adj, f -zna 'hiter', tudi brzân, n brznộ (<*b̂ิrzbnı (ap C)), ki ga potrjuje tudi zahodno slov. gradivo s p. bardzo adv 'zelo, močno, izredno, dobro' < psl. *b̂ิrzo. Pomenski razvoj 
se je torej realiziral na podlagi percepcije, da je ljubko, čedno, lepo ... izredno, odlično, izvrstno táko, ki je hitro.

Gutsmanov zapis bresen lahko ob njegovem bersen predstavlja tiskarsko napako.

\section{- brzen 1}

\section{bula ${ }^{2}$} ESSJ Ø

búla f 'grič' (nad. (Jeronišče, Livek) - SLA), ter. búla 'isto' (Kred - SLA), búla 'hribček' (Spinozzi Monai 2009: 107), bovš. bú:la 'grič' (Ivančič Kutin 2007), tolm. búla 'grič', 'oteklina' (DTZ 1993: 179).

(T) Denom adj tolm. 'bu:last, f - $a$ 'gričevnat' (Čujec Stres 2010).

(O) V nad. je pogosto sestavina večbesednih v mtpn, prim. Гó:mpuua bú:la, Jú:rcova bú:la, Na bú:l, Pod Гò:mpoú bù:lo, Žuà:nova bú:la (Šekli 2008: 58, 81, 93, 131), ter. búla svétā үbrnója 'hribček svetega Jerneja = Bartolomeja, it. Monte S. Lorenzo’ (Spinozzi Monai 1.c.).

IsIn. *'bu:la 'manjša vzpetina, hribček' (zahodno).

() Po metafori nastalo iz sln. búla 'oblasta oteklina', čeprav ni mogoče povsem izključiti, da se geografski termin metaforičnega izvora ni razvil iz pomenske stopnje 'glava', ki jo potrjuje tolm. 'bu:la f 'glava', npr. 'bu:la mə 'bali 'glava me boli' (Čujec Stres 2010).

\section{- bula 1}

\section{buta $^{1}$ ESSJ búta}

búta f 'tepec' (Pleteršnik po Cafu in Levstiku); v narečjih: štaj. zgsav. 'buta f 'neumna, nespametna ženska' (Zadrečka dolina - Weiss 1998), prleš. bùta f 'neumnica' (Rajh 2010) z izostankom labializacije zaradi ekspresivnosti besede (prim. Furlan 2016: 105s.).

(T) Denom adj bútast, f - $a$ 'omejen, neumen, nespameten' (SSKJ), cerklj. 'butast ‘čudaški, omejen' (Kenda-Jež Diss. 2002: *26), črnovr. bûtast 'neumen' (Tominec 1964), štaj. zgsav. 'butast 'neumen, nespameten' ob 'trd (o kruhu)' (Zadrečka dolina - Weiss 1998), pkm. 'butaste 'butast' (Gornji Senik - Bajzek Lukač 2009), bútasti 'neumen' (Porabje - Mukič 2005), stpkm. bùtasti 'neumen, zabit' (Novak 2006); denom subst pkm. bútaš m 'cepec, butec' (Porabje - Mukič 2005). ¿ ${ }^{H}$ 19. st.: bútaft 'verstockt, tölpisch' (Murko 18331).

Isln. *búta $\mathrm{f}$ 'tepec' $\leftarrow$ 'kij, tolkač'.

- Sln. adj bútast je enako srb. dial. bütast 'neumen' (Vojvodina - RSGV: 1, 158).

() Gotovo korensko sorodno s sln. bútati 'suvati, tolči, udarjati'. Ker se ekspresivne oznake tipa tepec 'omejen, neumen človek' pogosto razvijejo iz poimenovanj za palice, gorjače ipd., kot ponazarja tudi $\operatorname{sln}$. razmerje bútec 'tepec' (SSKJ) : 'kij, tolkač' (Gutsman), je verjetno, da je psl. deverbativ 
*büta, potem ko je v glagolu *bütati prišlo do pomenskega razvoja v 'tolči, udarjati, suvati' iz 'pihati', kot nomen instrumenti pridobil pomen *'tolkač, kij ipd.'. Bezlaj ESSJ: I, 55 je búta 'tepec' že uvrstil v slov. polisemantično besedno družino *bütati, enako je ta sln. leksem v ÈSSJa: 3, 101s. uvrščen med pomenske odtenke psl. deverbativa *büta.

V EWU: 150 se zaradi madž. gradiva, kot je buta 'neumen', butus 'isto' poleg 'tepček', sln. adj bútast izvaja iz madžarščine, kar je zaradi slov. besedne družine *bütati bolj verjetno prav obratno, da je bilo madž. buta izposojeno iz slov. Tudi č. dial. but'och 'nerodnež' je kljub Machku 1968: 78, ki sklepa o madž. izposojenki v češčini, bolj verjetno slovanskega izvora in tvorjenka tipa *szp'ohs 'kdor rad spi, zaspane' = p. śpioch 'zaspane' $\leftarrow *_{\text {sbpati }}$ 'spati' (SP: 1, 73) iz glagola *bütati 'tolči, udarjati, suvati'.

\section{- butati}

buta $^{2}$

ESSJ Ø

buta f 'bula' (bkr. - Šašelj 1906).

Psln. *buta f 'bula' (bkr.).

- = hrv. kajk. bưta f, g butế 'golša, gnojna oteklina pod svinjinim vratom' (Gola - Večenaj - Lončarić 1997), srb. dial. büta 'bula, izrastek (na telesu človeka, živali ali dreves); drevesna grča’ (Rečnik SANU), toda blg. dial. búca 'oteklina, izrastek' (citirano po ÈSSJa: 3, 103);

$<$ psl. dial. *büta f 'bula' (ap A).

() Zaradi p. buta 'nadutost, ošabnost, ponos, predrznost', stp. bucić się 'ošaben biti', ukr. dial. butá f, g -tý 'ponos, oholost, ošabnost, napuh', butáty -áju 'ponosen biti, ošaben biti', bútnyj 'ošaben, nadut', ki je do sln.-hrv.-srb. *büta $\mathrm{v}$ primerljivem pomenskem razmerju kot korensko medsebojno sorodno sln.

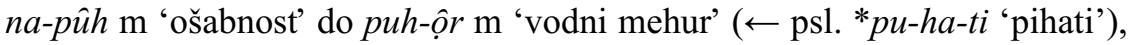
je bula/izrastek s subst *büta/bütbca f 'bula' označena kot napihnjen/otekel predmet in odraža psl. deverbativ *buta 'pihanje/otekanje/večanje ( $\rightarrow$ nadutost)' glagola *bütati, a ne iz pomenske stopnje *'suvati, udarjati, tolči' (prim. hrv. bütati 'suvati'), kot se domneva v SP: 1, 455 in ĖSSJa: 3, 101s., ampak bolj verjetno iz prvotnejše 'pihati ( $\rightarrow$ suvati ...)', ki jo še potrjuje korensko soroden glagol *bu-ha-ti (prim. sln. zabúhel, f - hla 'otekel = napihnjen') in *büla, prim. sln. búla 'oteklina, nabreklina', hrv. gradišč. bùla 'bula', p. dial. buła 'krogla, bula'.

\section{- butati}

\section{buta $^{3}$}

ESSJ s.v. búta

búta f 'debeloglavec (o človeku)’ (Pleteršnik po Miklošičevem slovarskem gradivu).

(T) bûtec m, g -tca 'debeloglavec' (Pleteršnik), butec 'Grosskopf, glavač, glavan, debeloglavec' (Cigale 1860); bútělj 'Grosskopf' (Janežič 1893) /butəlj/. 
Isln. *buta f 'debeloglavec' Ł slov. adj *butb 'debel' ali sln. butoglavac 'debeloglavec'.

- Prim. pomensko najbližje r. dial. butétb 'rediti se, debeliti se', butúz m 'debelušček', ukr. butity 'rediti se, debeliti se' (Vasmer: I, 253).

() Pomenski odtenek 'debel' se je v slov. besedni družini *but- enako kot v *bot- ( - botiti se) verjetno razvil iz predstopnje * 'otekel/napihnjen’ = *'okrogel' (Bezlaj ESSJ: I, 55). Sem je treba priključiti sln. butoglávec m, g-vca 'paglavec (žabji mladič) = Kaulkopf' (Povžane - Pleteršnik po Erjavcu, LMS 1879, 130), tj. *'debeloglava (žaba)', iz česar je po krnitvi lahko nastalo butèc m, g -tcà 'paglavec (žabji mladič)' (Lašče - Erjavec 1.c.). Kompoz nakazuje na obstoj psl. adj *butb 'debel', zaradi česar sta r.-ukr. glagola *butěti verjetno denominativa, sln. búta 'debeloglavec (o človeku)' pa je lahko substantivizirani adj tipa psl. *lüda $\leftarrow$ adj *lûdb (o tem Furlan, SR 51/posebna številka, 2003, 13ss.) ali pa je nastal po krnitvi kompoz *butoglavac*'debeloglavec (o človeku/živali)' <*buto-golubcb $\leftarrow$ adj *buto-golub(inb) 'tak, ki ima debelo/ veliko glavo'.

\section{- butati}

bûtec m, g -tca 'neumen, omejen človek' (SSKJ); v narečjih: rovt. črnovr. bûc 'zabit človek' (Tominec 1964).

(O) Onimizirano v Bevkovem atpn Butec, ki je tudi naslov njegove črtice, v kateri razloži Sin je bil slabotnega telesa, a debele glave, a kljub debeli glavi počasne pameti, zato so ga klicali za Butca. (Bevk, Butec, 1938/1939; vir: dLib.si). Pomenska obrazložitev atpn nakazuje, da se je zaradi dveh pomenov 'debel' in 'zabit, neumen' osnove but- sém 'debel' začel povezovati s sémom 'zabit, neumen ipd.'.

Isln. *'bu:tac m 'kij, tolkač' $\rightarrow$ 'neumen, duševno ali duhovno omejen človek'.

(E) Že v slovenščini verjetno pomensko razvito iz sln. butec 'kij, trkelj', kar je v 18. st. izpričano pri Gutsmanu: butez 'Schlägel, kiz, kizhiz, terkel, nabijazh, nabijalu, trepaunik, butiza, zhiz' /butec/. K pomenskemu razvoju prim. sln. tépec 'omejen, neumen človek' in 'kij, tolkač' (Pleteršnik; SSKJ). Izhodno *butbcb *'tolkač' je deverbativni nomen agentis iz glagola *bütati 'suvati, udarjati, tolči' = sln. bútati. K besedotvorju prim. sln. têpec $\mathrm{k}$ têpsti 'tolči, udarjati' (SP: 1, 100).

\section{- butati}

\section{butelj 1}

ESSJ s.v. búta

bútelj m, g -na/-tlja 'neumen, omejen človek' (SSKJ); v narečjih: kor. obir. bú:tal m, g -na/-a 'Provinzler, Dickschädel' (Karničar 1990), primor. jnotr. bûtal (Dolnje Vreme - Rigler 1963: 35), bovš. bú:tle m, g -telnal-tęlne 'tepec, 
butelj, neumnež' (Ivančič Kutin 2007), rovt. črnovr. bûtl m, g -na 'zabit človek' (Tominec 1964), tolm. 'butli indecl 'neumnež' (Čujec Stres 2010), štaj. zgsav. 'but'l m, g -na 'omejen, neumen človek' (Zadrečka dolina - Weiss 1998), panon. pkm. 'butle m, g -ẹna 'butec' (Gornji Senik - Bajzek Lukač 2009), prleš. 'butl m, g -la 'neumnež, prismoda' (Rajh 2010).

(T) Strukturalno izpeljanko v cerklj. 'butlc m, g - $a$ 'omejen, neumen človek' (Kenda-Jež Diss. 2002: *26) lahko posredno potrjuje štaj. zgsav. dem 'but'ločək m, g -čka (Zadrečka dolina - Weiss 1998).

(O) Cgn Butelj (ZSSP) *'neumen, duševno ali duhovno omejen človek, tepec'.

Psln. *butal' m 'neumen, duševno ali duhovno omejen človek, tepec' (splošno).

- Prim. r. dial. bútlja 'grob, robat, nekultiviran človek, tepec' (arhang., pskov.). $<$ psl. dial. nomena agentis *butbl'b in *butbl'a (?).

() Anikin: 5, 220 ni poznal slovenske ustreznice in je kot možno razlago za r. bútlja navedel metaforični prenos iz r. bútlja 'steklenica, večja steklenica', kar ni prepričljivo. Sln.-r. besedi sta gotovo korensko sorodni s sln. sin búta $\mathrm{f}$ 'tepec' in bûtec m 'tepec' (Bezlaj ESSJ: I, 55), a je v tej slov. besedni družini težko ugotoviti, ali sta sln. in r. samostalnik izpeljanki tipa brada 'barba' $\rightarrow$ bradelj 'kar je v zvezi z brado = obradek' iz búta 'tepec' $(-$ buta') ali pa deverbativna nomena agentis tipa tŕkelj $\mathrm{m}, \mathrm{g}-k l j a$ 'tolkač' $\leftarrow$ tŕkati 'tolči ipd.' iz glagola *bütati 'suvati, udarjati, tolči' z enakim pomenskim razvojem kot $\mathrm{v} \sin$ bûtec 'tepec' $\leftarrow$ 'kij, tolkač'.

Fonetično in pomensko neprepričljivo izvajanje iz nepreglašene oblike srvn. bütilo 'birič' (Ludvik, Linguistica I, 1955, 67s.; isti, JiS IV, 1958/59, 222) je zavrnil že Bezlaj 1.c.

- butati

butelj $^{2} \rightarrow$ butolj

ESSJ Ø

butira ESSJ $\emptyset$

butiera f 'hruška maslenka' (cerklj. - Razpet 2006), bu'ti:ra f 'sočna pozna hruška rjave barve' (Kenda-Jež Diss. 2002: *26), toda nad. butier m 'vrsta hrušk' (Špehonja 2003 s.v. pera), butier m, pl butieri 'vrsta okroglih in temnih hrušk' (Rigoni-Salvino 1999 s.v. pera).

Isln. *bu'ti:r m 'hruška maslenka' (zahodno);

verjetno pod vplivom generične oznake hrûška 'pirum' feminizirano v *bu'ti:ra.

$\diamond \quad$ it. trž. (pero) butiro 'maslena hruška = maslenka' (Doria 1987) z adjektiviziranim subst butirro 'maslo', srlat. butirum 'smetana', lat. bütȳrum 'maslo'

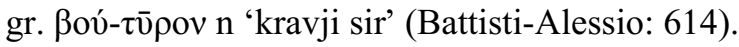

() Hruške z mehkim in sladkim mesom so s temeljnim sémom 'maslo' motivirane tudi v it. pera burrona 'hruška maslenka' $\mathrm{k}$ burro 'maslo' (Battisti-Alessio: 640), frc. beurré 'hruška maslenka' k beurre 'maslo', n. Butterbirne 
'maslenka' k Butter 'maslo'. Sln. sin maslẹnka 'hruška z mehkim in sladkim mesom' (SSKJ), maslenka 'Butterbirn' (Cigale 1860) $\longleftarrow{ }^{*}$ maslena hruška je bil poslovenjen iz sln. pûtrnica f 'maslenka' (Pleteršnik), puternica (Cigale 1860 s.v. Butterbirn), 3 plemena žlahtnih puternic (Kmetijske in rokodelske novice IV, 1846, 202; vir: IMP) '3 vrste žlahtnih maslenk', črnovr. pûtranca 'vrsta hrušk' (Tominec 1964), kalka po n. Butterbirne: sln. púter m, g -tra 'maslo' $\rightarrow$ *putr-na hruška $\rightarrow$ putrn-ica.

'bütọl m, g - a 'vrsta jabolk' (prleš. - Rajh 2010), butolj 'Name eines Apfelbaumes' (Janežič 1851).

† butolẹnka f 'neko jabolko' (mariborska okolica - Erjavec, LMS 18821883, 1883, 316).

$\oplus$ 19. st.: bútolj m 'Name eines Apfelbaumes' (Murko 1833¹).

Isln. *'bu:tol' m 'vrsta jabolk'.

(E) Nejasno.

Erjavec 1.c. je v mariborski okolici zabeležil tudi bútelj 'vrsta jabolk', kar Pleteršnik predstavlja s pomenom 'vrsta debelih jabolk', a sln. dial. *'bu:tol' ne more biti fonetično razvito iz tega leksema, možno pa je, da je z njim korensko sorodno in oboje izpeljano iz psl. dial. *büta *'nekaj napihnjenega, otečenega, okroglega, debelega ipd.' (prim. sln. dial. búta 'bula' : búta 'debeloglavec'). K variantnemu besedotvorju prim. *bobbl'b : *bobol'b $\leftarrow{ }^{*} b q b a$ 'mehur, izrastek na telesu/rastlini' (SP: 1, 109).

\section{- buta ${ }^{2}$}

$\operatorname{col}^{3}$ ESSJ cộl II cộl m, g - a 'klada' (Pleteršnik po Cafu), cole za drva žagati (Pleteršnik po $\mathrm{Cafu}$ ); cole imenujejo male lesene krhlje, s katerimi po zimi netijo, da vidijo predice presti (Solčava na Štajerskem - Pleteršnik); v narečjih: kor. podjun. cwá:w m 'z drevesnega debla odžagan kos lesa' (TSVK).

(T) Denom cọ́liti -im impf 'cole za drva sekati ali žagati’ (Pleteršnik po Cafu); kor. podjun. dem cò:lej 'majhen, z drevesnega debla odžagan kos lesa', kol có:lje 'z drevesnega debla odžagani kosi lesa' (TSVK; Zdovc 1972: 94).

Isln. *'co: $\ell \mathrm{m}$ *'odžagan kos lesa'.

• srvn. zol m 'kos cilindrične oblike, drevesna klada, drevesno deblo; čep, klin, zatič' (Lexer: III, 1147), bav. n. Zoll m, Zollen m, f 'kepa cilindrične oblike; klada' (Pleteršnik; Striedter-Temps 1963: 104; Bezlaj ESSJ: I, 67).

() V severni Nemčiji je srvn. zol v 15. st. začelo označevati dolžinsko mero približno $2,5 \mathrm{~cm}\left(-\right.$ cola $\left.^{2}\right)$ in izpodrinilo starejši srvn. dîme 'palec' in vinger 
'prst', zaradi česar je možno, da je srvn. zol prvotno pomenilo *'krajši odrezan kos lesa' (Pfeifer5: 1622).

drogva

ESSJ Ø

drogva f 'droga' (Kartoteka SSKJ; Besedišče 1987).

Isln. drogva f 'droga'; knjižna izposojenka.

$\diamond \quad$ nvn. zastarelega Drogue 'droga', danes Droge 'isto'.

Beseda drogva predstavlja repliko nvn. pisne variante Drogue, ki se je do uveljavitve zapisovanja Droge uporabljala kot citatna beseda iz frc. drogue 'droga', tudi droguerie (Furlan 2016: 53 z op. 99).

- droga

flum 1

ESSJ Ø

f'lym m 'velika reka' (istr. šavr. (Boršt) - Giljanović Diss. 2011: 435).

Isln. dial. *f'lu:m m 'reka' (Istra).

$\diamond \quad$ istr. rom. *flum m 'reka'.

(E) Tako kot na Krku potrjeno floim 'reka' (Bartoli 1906: II, 346), v Miljah flun 'isto' (Zudini-Dorsi 1981), furl. flum, flun (NP), stfrc. flum, prov. flum (Meyer-Lübke: 3388) in it. fiume fonetično razvito iz rom. *flume 'vodni tok = reka' < lat. flümen $\mathrm{n}, \mathrm{g}$-inis 'tok = tekoča voda; reka', kar je nomen actionis iz fluō -ere 'teči (o vodi)' (Furlan, MR 2016: 157-160; Giljanović 1.c.; de Vaan 2008: 228).

flum ${ }^{2}$

ESSJ Ø

flum m 'mivka', npr. Dal na Rik sa načidal za cíu kamjúon fluma 'Doli pri Reki so natovorili za kamion mivke' (cerklj. - Razpet 2006), cerklj. f'lum m, g - $a$ 'mivka', tudi f'lun 'isto' (Kenda-Jež Diss. 2002: *74).

(T) Denom adj v cerklj. f'lumast, f - $a$ 'mivkast, peščen', npr. f'lumasta 'zemle (Kenda-Jež l.c.).

(O) Sem mtpn Flum 'parcela v naselju Batuje v o. Ajdovščina', 'parcela v naseljih Dolnji Zemon, Šembije, Mala Bukovica, Velika Bukovica, Tominje, Vrbovo v o. Ilirska Bistrica', 'parcela v naselju Šembije v o. Ilirska Bistrica' (LiAK), mtpn Flumlje kol 'parcela v naselju Vrbica v o. Ilirska Bistrica' (LiAK), mtpn Flumje kol 'parcela v naselju Koseze v o. Ilirska Bistrica' (LiAK) , F'lume 'močvirje v gozdu' (Čadrg - Ivančič Kutin, Traditiones 35/1, 2006, 148).

Isln. dial. *f'lum m 'mivka = droben pesek = prod' (zahodno).

$\diamond \quad$ rom. *flume m 'vodni tok; naplavina', nato v sln. 'mivka'.

() Gotovo izposojenka iz istega rom. leksema kot sln. istr. šavr. f'lym m 'velika reka' ( - flum$^{1}$ ). Ker areal izposojenke obsega tako cerkljansko kot notranjsko narečje (Ilirska Bistrica, Ajdovščina) in ker refleksi rom. *flume 'vodni tok, reka' < lat. flümen n, g -inis 'tok = tekoča voda, reka' pomena 
'mivka = droben pesek' ne potrjujejo, čeprav se iz prvotnega pomena 'vodni tok' lahko realizira, kot ponazarja psl. *próds m 'vodni tok; kar vodni tok naplavi na obrežje $=$ naplavina $=$ kamenje ipd.', prim. sln. prôd $\mathrm{m}$ 'kamenje, ki ga je nanesla, zaoblila voda' (SSKJ), toda ukr. prúd 'hitri vodni tok', č. proud 'tok, curek', je verjetno, da se je izposoja iz rom. predloge *flume realizirala še v generični pomenski stopnji 'vodni tok' in da je rom. izposojenka šele v sln. pridobila pomen 'mivka'. K temu napeljuje tudi tolm. flúm m 'naplavljeno blato' (Most na Soči - Kenda 1926), ki lahko predstavlja vmesno pomensko stopnjo od 'vodni tok' do 'mivka = droben pesek', tj. 'naplavina'. Posebno pomensko specializacijo, morda iz pomenske stopnje 'naplavina', izpričuje samo v Parjah na Notranjskem zabeleženo flŷm 'žabji mrest' (SLA) $<$ sln. *flu:m, kjer je do take leksikalizacije lahko prišlo, ker žabji mrest kot otoček plava na vodni gladini, dokler ga vodni tok ne naplavi na obrežje. O tem Furlan, MR 2016: 160-169.

hardigata $\rightarrow$ ardigata

ESSJ Ø

\section{hardun}

ESSJ Ø

härdûn interj za izražanje podkrepitve trditve, npr. hardun, kako ste pridni (pog. - SSKJ).

(E) Interjekcija v vlogi blažje kletvice je nastala po križanju med sinonimnima kletvicama hardigata in mëjdûn/mệjdūn, ki izražata podkrepitev trditve $(\mathrm{SSKJ}): \underline{\text { hardigata } \times \text { mejdun }} \rightarrow$ hardun (Furlan, JZ 24/1, 2018, 133).

\section{- prmejdun - hardigata}

\section{harduš}

ESSJ Ø

'xa:r'duš interj za izražanje podkrepitve trditve (štaj. zgsav. (Zadrečka dolina) - Weiss 1998).

(E) Kletvica je posledica križanja med kletvicama hardigata in prmëjdū̌s/ prmejdûš, ki izraža močno podkrepitev trditve (SSKJ): hardigata $\times$ prmej $\underline{\text { huš }}$ $\rightarrow$ harduš (Furlan, JZ 24/1, 2018, 133).

\section{- prmejduš - hardigata}

\section{hlapec $^{2}$}

ESSJ s.v. hlâpec

hlâpec m, g -pca 'sezuvač, zajec', npr. s hlapcem si je sezul škornje 'z zajcem/s sezuvačem si je sezul škornje'; beseda označuje tudi druga različna orodja, ki služijo kot opora, podstava, pomoč pri kakem opravilu, npr. gospodinja je naslonila burkle na hlapca in porinila lonec $v$ peč '... na podstavek ...'; stal je na hlapcu in jemal snope iz kozolca '... na zdevalnem stolu = pripravi, na kateri stoji človek, ki snope žita v kozolec zlaga ...' (SSKJ; Pleteršnik); v narečjih: bovš. hlà:pc 'lestvi podobna pregrada v jaslih' (Ivančič Kutin 2007), črnovr. ұłâpc 'priprava za sezuvanje čevljev; 
priprava pri kozolcu za podajanje snopja; priprava, na katero se naslonijo burkle ali lopar, ko se podaja v peč', 'nategač, z njim se pritrdijo doge na stavnik', 'železna priprava namesto zglavnika v peči' (Tominec 1964), štaj. zgsav. x'łåpac, g - pca 'zdevalni stol; sezuvač' (Zadrečka dolina - Weiss 1998), pkm. lápec 'sezuvač' (Beltinci - Novak 1996).

Isln. *hlápac m 'orodje za ...' (splošno).

$\diamond^{\mathrm{K}}$ nvn. Knecht, ki označuje različna orodja za nošnjo, oporo ipd.

Prim. tudi hrv. hläpac 'orodje za obdelovanje lesa' (Rijeka - ARj), kajk. hlapecz 'vrsta naprave v kuhinji' (Belostenec), hläpac, g - pca 'priprava za obračanje ražnja' (Jurančič 1986), läpac, g -pca 'sezuvač' (Žumberak - Skok, JA 33, 1912, 364), hlạpẹc, g -pca 'isto' (Lipljin 2002), čak. hlapëc, Npl hlapcì 'žebelj, ki povezuje jarem s plugom' (Orlec na Cresu - Houtzagers 1985), hläpoc, g -pca 'leseni zatič' (Turčić 2002), r. holóp 'sezuvač' (Dalb), p. chłopiec 'sezuvač; podstavek, ki se rabi pri izdelavi sira', pomor. xłopc 'sezuvač' (Lorentz).

(E) V slovenščini tako kot v posameznih drugih slov. jezikih so to kalki po nvn. Knecht, ki poleg 'hlapec, servus' označuje tudi različna orodja, ki človeku služijo kot opora, podstava, pomoč pri kakem opravilu (Grimm: 11, 1396). Iz tega simpleksa je bilo izposojeno hrv. kajk. knệht 'sezuvač' (Lipljin 2002). Zaradi polisemantičnega nvn. Knecht 'orodje/naprava za ...' so bila za potrebe po razlikovanju, katero orodje Knecht označuje, tvorjena kompoz Stiefelknecht 'sezuvač' ( $\leftarrow$ Stiefel '(visoki) škorenj' + Knecht 'hlapec'), tirol. n. pfànneknecht 'breznožni podstavek za ponev' (Schöpf: 328) itd.

\section{- hlapec ${ }^{1}$}

\section{ibovina} ESSJ $\emptyset$

Ïbovina f 'cvetnonedeljska butara' (pkm. (Beltinci, Hotiza) - SLA), pkm. ïbavna 'isto' (Turnišče - SLA).

Isln. *ibovina 'velikonočna butara, presnec' (pkm.).

() Ker je leksem v Beltincih homonimen z ibovina 'iva (vrbje)' (Novak 1996) < sln. dial. kol *ib-ov-ina, je najbolj verjetno, da se je pomen 'cvetnonedeljska butara' prenesel iz prvotnega kolektivnega 'vrbovo šibje = ivovo šibje', ker so na tem območju za izdelovanje cvetnonedeljske butare morali uporabljati predvsem šibje vrbe iva $=$ Salix caprea.

$\mathrm{Na} \mathrm{SZ}$ sln. območju se ftn $i v a \mathrm{f}$ 'Salix caprea' in njegove tvorjenke sporadično pojavljajo v fonetični realizaciji $i b a \mathrm{f}$ 'Salix caprea', npr. slngoriš. $i b a$ f 'Salix caprea' (ob Ščavnici - Pleteršnik), prleš. 'i:ba 'iva' (Rajh 2010), adj ibov 'bachweiden' (Cigale 1860), prleš. ibovec 'vrsta vrbe' (Središče ob Dravi - SLA), íbovec m, g -vca 'neka iva, ki je večja od navadne' (Pleteršnik po Cafu). Na to fonetično dejstvo je posredno opozoril že Bezlaj ESSJ: I, 214 s.v. iva, neposredno pa Furlan, JZ 18/1, 2012, 59ss.

\section{- iva}


later ESSJ Ø

lâtər m, g -tra 'mož, soprog', pl lâtri/lọtri (kor. (Lovrenc na Pohorju) - SLA 1.1: 276; SLA), kor. lâter 'isto’ (Ribnica na Pohorju, Lobnica - SLA 1.1 1.c.), lâtər 'mož' (kor. (Sveti Primož na Pohorju, Vuzenica, Zgornja Kapla) - SLA 1.1 1.c.).

IsIn. *'la:tər m, g *'la:tra 'mož', deloma verjetno tudi *'lo:tər 'isto', prim. pluralno obliko v Lovrencu na Pohorju.

() Nejasno.

Ajevski korenski vokal v govorih, kjer je oblika *'la:tər izpričana, ni mogel nastati iz ojevskega, prav tako tudi ne ojevski v pl lọtri iz ajevskega.

Pleteršnik po Cafu za območje Pohorja navaja, da se subst lọ́ter m, g -tra 'nemoralen, slab človek' kot izposojenka iz srvn. loter 'pridanič, navihanec; burkež' (Striedter-Temps 1963: 172) uporablja v pomenu 'možak, dedec' in tudi kot zaničljiva oznaka za soproga, a internoslovenski pomenski razvoj 'baraba, ničvrednež' $\rightarrow$ 'soprog' ni verjeten zaradi tirol. n. lotter, ki se uporablja tudi kot nevtralna oznaka za moško osebo nasploh, v južnem Poinju pa označuje ljubčka (Schöpf: 399).

\section{- loter}

letka

ESSJ lêtka

lệtka f 'vreteno pri kolovratu' (Pleteršnik), letka 'Spulradspindel' (Cigale 1880: 111, 155, z navedbo, da gre za terminološko izposojenko iz hrv.).

Isln. lệtka f 'vreteno pri kolovratu'; knjižna izposojenka.

$\diamond \quad$ hrv., srb. lëtka 'železna palica na vretenu, na katero se natakne cev, ko se navija preja' (Karadžić; Rečnik SANU), čemur pomensko ustreza mak. letka 'isto' in blg. dial. lètka 'vreteno pri kolovratu' (Bezlaj ESSJ: II, 137);

iz jslov. jezikov (srb. ali blg.) je bilo izposojeno romun. letcă f 'Spuleisen' (Bernard, RÉS 27, 1951, 34; Tiktin);

< jslov. tkalski termin *lètka; temu formalno ustreza hrv. lëtka 'kdor hitro in lahko hodi' (ARj), blg. lètka 'ptica' (Rečnik BAN), letkà 'deska, letva' (BER: III, 374), r. dial. lëtka 'letanje', 'kar teče', 'žrelo pri panju', ‘žleb, po katerem pada moka iz žrmelj', ukr. dial. lbotka 'žrelo pri panju', br. dial. lëtka ‘žrelo pri panju', 'večja šibra', 'deščica pri žrelu v panju', stč. létka 'ptica; katera koli leteča žival', č. letka 'močno pero v perutnici', slš. letka 'močnejše pero v peruti ali repu ptic', p. lotka 'perutnično pero' (Bezlaj 1.c.; ÈSSJa: 14, 151ss.); < psl. *lèt-rka f je deverbativ iz *letěti 'volare/currere' (Bernard 1.c.; Bezlaj 1.c.; ÈSSJa 1.c.) s prvotno slovnično funkcijo nomena agentis (prim. blg. lètka 'ptica') in nomena actionis (prim. r. dial. lëtka 'letanje'). Iz slednje funkcije so se razvila nomina loci (prim. r. dial. 'žrelo pri panju', ‘žleb ...'), prek nomina instrumenti s pomenom 'krilo', pa tudi 'pero ...'.

() Osrednji sém jslov. tkalskega termina 'palica/palčka' je mogoče primerjati s sémom 'deščica' v br. dial., zaradi česar je možno, da je do pomenskega 
razvoja 'žrelo pri panju' $\rightarrow$ 'palica/deska pri panju' $\rightarrow$ 'palica' po metonimiji prišlo v čebelarski terminologiji gozdnega čebelarstva, ker je bilo žrelo pri naravnem panju znak, kje mora čebelar vanj zarezati, da bi iz njega pobral med, kasneje pa je zarezo prekril s palicami/deskami. Ker podobno pomensko razmerje odraža jslov. *lètua 'letev' v odnosu do r. dial. lëtva f 'odprtina v čebeljem panju' $\leftarrow$ psl. nomen actionis *letuo n 'letenje' itd. (Furlan, Studia Borysiana 2014: 154ss.), je kljub Bernardu 1.c. in ĖSSJa 1.c. imel verjetno prav Skok: II, 291, ki je sklepal o korenski sorodnosti med jslov. *lètua 'letev' ( $\bullet$ letev) in hrv. lëtka ‘železna palica na vretenu' ter sorodnim.

\section{- leteti}

lọter m, g-tra 'nemoralen, slab človek', na Pohorju zaničljiva oznaka za fanta (Pleteršnik), stpkm. loter, g -tra 'prešuštnik, nečistnik' (Novak 2006); v narečjih: kor. rož. lótr 'lenuh' (TSVK).

(T) Fem lọtrica 'nemoralna ženska'; adj lọtrast 'nemoralen', lọtrski 'isto', lotrîv, f -iva, lọtrn; iz slednjega adjektiva subst lọtrnik 'nemoralnež', fem lọtrnica, lotrnîja 'nečistost, nemoralnost'; denom lotrováti -ûjem impf 'nečistovati' (Pleteršnik). TH 16. st.: lotraft 'Schalckhafftig, malitiofus' (Megiser 1592); 17. st.: ena lotriza, ali raven shena ali kuharza 'focaria', lotrica 'fornicatrix, kurba', gmain kurberska lotriza 'prostibula', lotrovati 'fornicari, fe kurbati', lotrovanîe 'fornicatio, lotria, kurbaria, nezhiftoft' (Kastelec-Vorenc); 18. st.: lotrèza 'Hure, Meretrix' (Pohlin), lotroufka podrepenza 'Schandhure, neframna kurba, neframniza, merhatinfka kurba, nemedludna zonta, kufla, zifa, ponudiga, zafuta' (Gutsman).

$\boxplus$ 16. st.: loter, lotar 'Bößwicht, Laur, Lecker, Lotter, Schalck' (Megiser 1592); 17. st.: loter 'ribaldo', 'fcelerato' (Alasia 1607) = 'lopov', 'hudodelec', en loter, kateri eno déklico ob diviftvu perpravi 'deflorator', lotar 'fornicator, kurbier', en loter 'planus, golúf, spelavez' (Kastelec-Vorenc); 18. st.: lôtr 'Hurer, Stuprator' (Pohlin), loter 'Hundsfutt, pefja luknja, sanikarnik, pefji tat', loter 'Schandbub, saframen zhlovek, neframnik', loter 'Unzichtiger' (Gutsman).

Isln. *'lo:tar m 'nemoralen, slab človek'.

$\diamond \quad$ srvn. loter/lotter 'pridanič, navihanec' ob adj 'lahkomiseln', bav. avstr. Lotter 'nemaren človek', kor. n. lotter 'lopov, baraba, lump', tirol. n. lotter 'oseba, ki ne naredi dobrega vtisa' (Striedter-Temps 1963: 172); izhodišče n. besedne družine, ki se v sodobni nvn. ohranja le še v glagolih lottern 'lenariti' in verlottern 'propadati, postajati zanemarjen', je stvn. lotar adj 'prazen, domišljav, ohol ipd.' (Kluge23: 526).

Ker je že v slovenščini 16. st. izposojenka loter močno besedotvorno produktivna (BSKJ), ni verjetno, da bi bila beseda šele nvn. izposojenka, kot je sklepal Bezlaj ESSJ: II, 152, sledeč Bernekerju: 735. Zaradi v stvn. neizpri- 
čane substantivizacije iz stvn. adj lotar ni verjetno, da bi bila izposojenka že starovisokonemška, kot je nakazal Miklošič 1867: 34.

Ker se ajevski korenski vokalizem pri tej n. izposojenki tako kot v sln. kor. lâter 'mož, soprog' pojavlja tudi v č. lotr/latr 'lopov, razbojnik', stč. lotr/ latr 'lopov, razbojnik' (Newerkla 2004: 596), v madž. pa prevladuje lator ‘lopov, razbojnik' (EWU: 876), je možno, da se je v sln., č. in madž. nemška izposojenka v korenskem vokalu preoblikovala pod vplivom neke sinonimne besede, morda pod vplivom panonskega latinizma iz lat. latrō m 'vojak, najemnik', kasneje 'ropar, razbojnik', a nemški viri izposojenke iz lat. latrō ne potrjujejo.

Sledeč Jungmannu: II, 353 Newerkla 2004 1.c. za č. lotr/latr 'lopov, razbojnik' sklepa o stari izposojenki iz lat. latrō, ki naj bi bila preoblikovana pod vplivom srvn. loter/lotter 'pridanič, navihanec'.

(D) BD

Srvn. lot (t)er 'pridanič, navihanec' ( $\leftarrow$ stvn. lotar 'prazen, domišljav, ohol ipd.')):

srvn. lot $(t) e{ }^{*}$ 'soprog'

srvn. loterbuobe 'pridanič, navihanec'

srvn. loterîe 'nečistovanje'

$\Rightarrow$ lotriš $\Rightarrow$ later $\Rightarrow$ lotrič $\Rightarrow$ lotrija

$$
\begin{array}{ll}
\Rightarrow & \text { sln. loter; } \\
\Rightarrow & \rightarrow \text { lotriš (?); } \\
\Rightarrow \mathrm{K} & \text { sln. later (?); } \\
\Rightarrow & \text { sln. lotrič; } \\
& \text { sln. lotrija. }
\end{array}
$$

(H) 16. st.: en hud pueb ali lotrizh (Trubar 1595: I, 176) 'neučljiv, trmast, nezvest fant'; 17. st.: en lotrizh, en prefherni klaffar, en pregnani loter 'scurra' (Kastelec-Vorenc).

(?) Prek vzdevka za malovrednega, nemoralnega fanta onimizirano v cgn Lotrič.

Isln. *lotrič m 'malovreden, nemoralen fant'.

$\diamond^{\mathrm{K}}$ srvn. loterbuobe 'pridanič, navihanec' (Lexer: I, 1963).

Sln. lotrič je bolj verjetno kot domača izpeljanka iz srvn. izposojenke lóter 'pridanič, navihanec' delni kalk iz srvn. kompoz loterbuobe, kjer je bil drugi člen buobe 'deček, fant' nadomeščen s sln. sufiksom -ič $<*$-it'b v manjšalno -slabšalni funkciji.

\section{- loter}

\section{lotrija ESSJ s.v. lóter}

lotrîja f 'nečistovanje' (Pleteršnik), stpkm. lotríja 'prešuštvo' (Novak 2006). $\boxplus$ 16. st.: lotria 'Schalckhait, piberia' (Megiser 1592); 17. st.: lotria, lotrovanîe 'fornicatio, kurbaria, nezhiftoft' (Kastelec-Vorenc); 18. st.: lotria 'Unzucht' (Gutsman).

IsIn. *lot'ri: f 'nečistovanje'; 
prestrukturirano v sln. ajevsko deklinacijo kot *lot'ri:ja.

$\diamond \quad$ srvn. loterîe f 'nečistovanje' (Striedter-Temps 1963: 172; Lexer: I, 1963) /lotəri/.

Srvn. loterîe je abstr iz srvn. loter 'pridanič, navihanec ipd.' .

\section{- loter}

\section{lotriš ESSJ Ø}

lotríš m 'nespodobnež' (Pleteršnik po Cafu).

Isln. ?.

() Čeprav leksem gotovo spada v besedno družino sln. lọter 'nemoralen, slab človek', ni jasno, ali je domača izpeljanka na -iš ali celo -uš (če izvira iz območja s $\operatorname{sln} . \ddot{u} / i<u$ ) iz sln. lọter ali pa izposojenka iz nvn. lotterisch 'lahkomiseln, razuzdan' (Grimm), ki je bila v sln. substantivizirana. Naglasno mesto v lotríš ustreza sln. kurvíš 'kurbir' (Pleteršnik) in kaže v prid prvi možnosti. Po podatku iz Pleteršnikovega slovarja naj bi bila beseda tudi kajkavska, a je dostopni kajkavski viri ne potrjujejo.

- loter

maslenka $^{1} \rightarrow$ butira ESSJ Ø

mejdun $\rightarrow$ mejduš ESSJ Ø

mejduš ESSJ $\emptyset$

mëjdūš interj za izražanje močne podkrepitve trditve, v enaki funkciji mêjdūš, npr. mejduš, kako je lačen, in möjdū̌s ob mọjdūšs, npr. mojduš, kako nas je zeblo (pog. - SSKJ).

Isln. *mejduš interj v funkciji kletvice in s pos pron mọ́j posodobljena varianta *mojdǔ́.

() Interjekcija v vlogi kletvice odraža evfemizacijo kletvice prmejduš s posodobljeno varianto prmojduš, in sicer s krnitvijo prve sestavine: *pr-mej$d u \check{s} \rightarrow$ mejduš; * ${ }^{*} r-m o j-d u \check{s} \rightarrow$ mojduš. Izvorna kletvica prmejduš je bila $\mathrm{s}$ sestavino tpn Dúnaj evfemizirana v *pr-mej-Dunaj > *pr-mej-dunej > *pr -mej-duni > prmejdun in skrajšana $\mathrm{v}$ mëjdûn/mẹjdûn ter mëjdūnaj/mệjdūnaj (pog. - SSKJ), pkm. mejdun (Gornji Lakoš, Lendava - Pšajd 2005: 72). O tem Furlan, JZ 24/1, 2018, 133 op. 6.

\section{- prmejduš}

mirodija

ESSJ Ø

mirodija f 'Spezerei' (Janežič 1908 s.v. miro-dáren) = 'dišava (kot začimba)' je slovarski hapaks legomenon.

IsIn. *mirodija 'dišava (kot začimba)'; knjižna izposojenka. 
↔ hrv. miròdija 'začimba' poleg 'koper', 'peteršilj', 'komarček', 'kolonialno blago’ (Furlan 2016: 57), srb. miròđija ‘isto’, kar je bilo izposojeno iz ngr. $\mu \nu \rho \omega \delta i ́ \alpha$ '(prijeten) vonj’ (Skok: II, 429).

() Ngr. $\mu \nu \rho \omega \delta i ́ \alpha$ '(prijeten) vonj' je nomen abstractum iz adj $\mu \nu \rho \omega ́ \delta \eta \varsigma$ 'di-

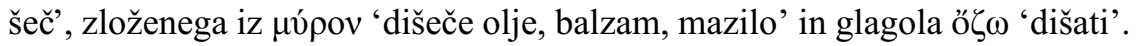
$\mathrm{Z}$ besedo $\mu v \rho \omega \delta i ́ \alpha$ je bil prijeten vonj poimenovan po vonju olj, mazil ipd.

\section{- mirodilnica}

\section{mirodilnica}

ESSJ Ø

mirodílnica f 'drogerija', npr. to mazilo dobiš v lekarni ali v mirodilnici (zastar. - SSKJ), miro-dílnica 'Spezereihandlung' (Janežič 1908 s.v. miro-dáren) $=$ 'trgovina $\mathrm{z}$ dišavami'. Beseda je bila v prvi polovici 20. st. še v rabi $\mathrm{v}$ časopisnem in leposlovnem, predvsem zahodnoslovenskem tisku (Furlan 2016: 51-56).

(1) Nomen agentis mirodilničar 'drogerist (?)', adj mirodilniški, npr. mirodilniško blago (oboje Kartoteka SSKJ).

Isln. *miro'di:lnica f 'drogerija'.

() Neuveljavljeni neologizem, ki je bil po vzoru nomenov loci na -ilnica (tip točilnica) najverjetneje v 19. st., da se ne bi uveljavila izposojenka iz n. Spezerei(handlung), umetno tvorjen iz sln. mirodija 'dišava (kot začimba)', prim. miro-dija 'Spezerei’ (Janežič 1908 s.v. miro-dáren; Besedišče 1987), kot izposojenke iz hrv., srb. miròdija 'začimba' poleg 'koper', tudi miròđija 'isto', kar je iz ngr. $\mu \nu \rho \omega \delta i ́ \alpha$ '(prijeten) vonj'; novogrška izposojenka je v hrv. oziroma v srb. prek prvotnega pomena '(prijeten) vonj' začela označevati nekatere dišavnice, poleg kopra tudi peteršilj in komarček, začimbe in kolonialno blago nasploh (Furlan 2016: 51ss.; Skok: II, 428s.).

Drogerija kot specializirana trgovina je bila $\mathrm{z}$ besedo mirodilnica poimenovana po svojem prvotnem prodajnem artiklu, tj. po posušenih dišečih zeliščih = začimbah.

Prav tako se v hrv. ni uveljavil neologizem mirodarnica 'prodajalna začimb', tudi mirodijarnica 'isto', kar je bilo tako kot nomen agentis mirodijar 'drogerist' (Šulek 1874-1875) izpeljano iz hrv. miròdija 'začimba'.

(D) ${ }^{B D}$

Hrv. miròdija 'začimba' ( $\rightsquigarrow$ ngr. $\mu \nu \rho \omega \delta i ́ \alpha$ '(prijeten) vonj’):

$$
\Rightarrow \text { sln. mirodija; }
$$

$\Rightarrow$ mirodija

$\rightarrow$ sln. mirodilnica.

ordigata $\rightarrow$ ardigata

ESSJ Ø 
oslak m 'Werg' (Cigale 1860) = 'pazderje = oleseneli deli stebelc lanu ali konoplje, ki se pri trenju ločijo od vlaken'.

$\boxplus$ 18. st.: oslak 'Werg, colus Jovis' (Pohlin), oflak'Werg, posdierje, posderje, kudelja, kofmata preja, kodela' (Gutsman); 19. st.: oflak 'Werg' (Murko $1833^{1}$ ), toda pri istem avtorju tudi ofljak (Murko 1833²)/osljak/, kar je morda napačen prepis Gutsmanove glose oflak/oslak/.

Psln. *ob-sulâk m 'pazderje' (<*ob-suolkb).

토 Ker se poimenovanje nanaša na olesenele dele stebelc lanu ali konoplje, ki so pri trenju ločeni = povlečeni od vlaken, je treba izhajati iz deverbativnega nomena actionis *ob-Sb-uolkb z rezultativnim pomenom * povlečena/slečena stvar' iz tranz glagola *ob-sb-uelk-ti/ob-sb-uelčešb *'dol/stran vleči = povleči = sleči', prim. z enakima prefiksoma hrv. čak. oslî́ se 'sleči se' (Susak ČDL: III, 540). Iz iste intranz glagolske predloge izvira tudi ftn oslâk m 'Convolvulus' s sin slâk 'isto' ( - oslak $\left.^{2}\right)$.

\section{- vleči}

\section{oslak $^{2}$}

ESSJ Ø

oslâk m, g - a 'Convolvulus sepium' (Pleteršnik po Erjavcu), 'Convolvulus arvensis' (Pleteršnik), oslak 'Ackerwinde, slak' (Cigale 1860); v narečjih: dol. oslák 'isto' (Lašče - Erjavec, LMS 1882-1883, 1883, 296).

Psln. *ob-sulâk m 'Convolvulus, slak' (<*ob-suolkb).

() Medtem ko ima sorodni sinonim slâk $<* s \ddot{b}-u o l k b$ ustreznice v drugih slovanskih jezikih (Furlan v Bezlaj ESSJ: III, 254), je besedotvorna varianta oslâk iz *ob-sb-uolkb v slov. svetu osamljena in brez ustreznic ter kaže, da sta bila refleksa psl. podstavnih intranz glagolov*ob-sb-uelk-ti/ob-sb-uelčešb se in *sb-uelk-ti/sb-uelčešb sę kljub različnim prefiksom ob tvorbi deverbativov *š̈-uolkb in *ob-Sb-uolkb sinonimna in da sta oba označevala dejanje, ko se nekaj vleče, opleta, oprijema okoli česa, prim. č. opletník 'Convolvulus', oponec 'isto' (Machek 1954: 184).

- vleči - sin slak

\section{plazem}

ESSJ Ø

plazem m 'šop las ali perja' poleg plasem m, g -sma 'kosem' (Janežič 1851), plasəm 'Flocke' (Janežič 1867), plasěm 'Schopf' (Janežič 1893)/plasəm/, plazem 'Schopf' (Cigale 1860).

(H) 18. st.: plasem 'Schopf, kop, zhop' (Gutsman)/-z-/; 19. st.: plásem 'Schopf' (Murko 1833²) /-z-/.

Psln. verjetno *pläzim m *'kar je navlečeno’, po redukciji *plázəm.

() Izhajati je mogoče iz substantiviziranega ptc prez pas *pläzimb glagola *pölziti sę = sln. pláziti se -im se 'vleči se, lesti, drseti' v pomenu *'(količina skupaj) navlečenih (stvari)'. Podoben pomenski razvoj je v tej besedni družini mogoče zaslediti v adv spläz 'skupaj', splâzom 'isto' (v 17. st. s’plajom 
'catervatim, s'kupom, s'voiskó' - Kastelec-Vorenc), splâzoma 'skupaj' (v 18. st. s’plasama 'Truppenweise' - Gutsman), kjer v predložnih zvezah tipa *s s plazomb nastopa sln. samostalnik plâz m 'lavina' (Snoj v Bezlaj ESSJ: III, 298), tj. *'plazenje'.

$\mathrm{S}$ sln. plazem je korensko sorodno v 18. st. samo pri Gutsmanu izpričano snežni plažmec: Jneshni plashmez 'Schneeflocke, fneshna muha' (Gutsman) /snežni plažmec/, tj. 'snežinka', le da je bil prvotni ptc tu substantiviziran s sufiksom *-bcb, -ž- namesto pričakovanega $-z$ - pa je v besedni družini pláziti lahko nastal pod vplivom nomena actionis * plaženje (prim. hrv. plaženje 'reptatio' - ARj) k pláziti.

V Pleteršnikovem slovarju je Janežičeva beseda plazem neustrezno predstavljena z medglasnim - $s$ - kot plásəm m, g -sma 'kosem, Flocke' in zato v ESSJ: III, 49 ni bila upoštevana.

\section{- plaziti}

primojdun $\rightarrow$ prmejdun

ESSJ Ø

\section{prmej}

ESSJ Ø

prmëj interj za izražanje podkrepitve trditve, npr. pravica mora zmagati; za prmej ti obljubim, da bom prišel (pog. - SSKJ) 'z gotovostjo obljubim, da bom prišel'. V narečjih nezabeleženo.

IsIn. * prmej interj v funkciji kletvice.

() Interjekcija v vlogi kletvice odraža evfemizacijo kletvice prmejduš, in sicer s krnitvijo njene zadnje sestavine: *pr-mej-duš $\rightarrow$ prmej (Furlan, JZ 24/1, 2018, 133 z op. 6).

\section{- prmejduš}

\section{prmejdun}

ESSJ Ø

prmejdun interj za izražanje podkrepitve trditve, prmejdun, kdo si upa kaj takega govoriti! (Kartoteka SSKJ), v enaki funkciji tudi primöjdûn, primojdûn, npr. primojdun, ravno prav si prišel, in primöjdūnaj, primojdūnaj, npr. primojdunaj, vino ni slabo (pog. - SSKJ).

IsIn. *prmej-dunaj, s pos pron mọ́j posodobljeno prmoj-dunaj, oboje interj v funkciji kletvice.

(E) To je evfemizirana kletvica, ki je iz prvotne prmejduš s posodobljeno varianto prmojduš nastala z zamenjavo izglasnega subst dúša kot enega temeljnih sestavin krščanske terminologije z nevtralno, nebogokletno sestavino tpn Dúnaj. Zamenjavo je spodbudilo enako vzglasje *du- obeh sestavin: *prmejduš/prmoj-duš $\rightarrow$ *prmej-Dunaj/prmoj-Dunaj > *prmej-dunej/prmoj-dunej $>$ prmej-dun/prmoj-dun (Furlan, JZ 24/1, 2018, 133 op. 6).

\section{- prmejduš}


prmejduš

ESSJ Ø

prmëjdūš interj za izražanje močne podkrepitve trditve, tudi prmejdūšs, npr. ne boš šel z nami, prmejduš; obljubil je za prmejduš, da pride 'obljubil je, da zagotovo pride', v enaki funkciji tudi primöjdūš ob primojdūš in primöjdúši ob primojdúši (vse SSKJ); v narečjih: kor. obir. par mé:jdù:š in parmò:jduš, parmojdù: ̌s, par mó:j dù:š (Karničar 1990: 287, 291, 311, 315, 333), primor. briš. parmiduš 'zagotovo' /parmi'duš/ ob parmiviar 'isto' (Korenjak 2012) /parmivi'ar/, dobesedno 'pri moji veri', rovt. tolm. par 'mej 'duš (Čujec Stres 2014 s.v. pridušati se), črnovr. par mẹi dûš (Tominec 1964 s.v. duša), dol. parmèj dù:š (Smole Diss. 1994: 164, 244), v Čabru prm'ojduš (Malnar 2008).

(T) V kor. obir. besedni zvezi parmó:jdù:šu wtràq v O:, parmó:jdù:šu wtràq, a te naj wstrelí:m (Karničar 1990: 291) 'O, prekleti otrok, ali naj te ustrelim’ je adj parmó:jdù:šu izvorno ptc na -al delokutiva *prmojdušati 'kleti’ $\leftarrow$ *'prmojduš izgovarjati', prim. enako iz interj prmejduš je prmejdušati v Z Lahoni smo se začeli po gostilnah na Vrhniki, prmejdušali smo, oni pa porkamadonali (Miško Kranjec - Kartoteka SSKJ).

$\boxplus$ 18. st.: per mojei dufhi 'Bey meiner Seele oder Treue' (Gutsman) z izglasjem -ei po adjektivni deklinaciji, prim. DLsg f (per) fvetei '(pri) sveti' (Gutsman 1777: 21).

(? Iz prmojduš v Ravni Gori onimizirano Prmajdušs 'vzdevek za Kranjca (in Slovenca) v smislu trdosrčnega, trmastega človeka' (Erjavec 2014).

Isln. *pri měji (< *moieini) duši * 'pri moji duši’ (Ramovš 1952: 93; Furlan, ŠM II: 171 op. 6), po redukciji sklopljeno prmejduš; posodobljeno s pos pron moj v *pri moji duši, po redukciji sklopljeno prmojduš (Furlan, JZ 24/1, 2018, 133 op. 6).

$\varsigma^{\mathrm{K}}$ srvn. prisežni formuli krščanske terminologije bî der sêle mîn 'bei meiner Seele = pri moji duši', npr. ich wil dir râten bî der sêle mîn 'želim ti svetovati pri moji duši' (Lexer: II, 864), npr. srvn. bî sêl und triuwe swern 'pri duši in veri priseči' (Pfeifer ${ }^{5}: 1268$ ).

Ni verjetno, da bi bila interj domačega izvora in z edinim sln. izhodiščem pri moji (krščeni) duši, kot sklepa Snoj 2016: 604.

Kalki z drugačno rekcijo *na moịo duš $Q$ se odražajo v hrv. čak. nã dušu mojü 'bei meiner Seele', npr. Nã dušu mojü, vïdi san ga kal je pasô (Dračevica na Braču - ČDL) ob srb. Döboga i do moje dûše 'resnično' (Elezović: I, 162 s.v. dûša), ukr. karpat. na mọju dúšu 'resnično, zares' (Nikolaev Tolstaja 2001: 80), p. na ma dusze 'isto', dial. Na moj dusiu! 'zares, pri moji veri' (Karłowicz SGP: I, 396), stč. bráti čso na svú dušu 'prisegati pri svoji duši', nč. na mou duši 'resnično', kot vzklik tudi 'prisegati, obljubljati' (Machek 1968: 135), slš. gemer. Na moj dušu, že som to nepódal (Orlovský 1982: 74).

() Sln. sklop prmejduš kot kalk po srvn. predlogi bî der sêle mîn se je po izstopu iz nevtralne krščanske terminologije skupaj s posodobljeno varianto 
prmojduš začel uporabljati kot močnejša kletvica in bil prav zato evfemiziran ali z zamenjavo subst dúša kot enega temeljnih sestavin krščanske terminologije z nevtralnim, nebogokletnim Dúnaj ( ( $\sim$ prmejkokoš) ali z izločitvijo zadnje sestavine dúša ( mejduš) ali pa prvih dveh ( $\square$ duš). Po križanju s kletvico ärdigâta ( $\square$ ardigata) je nastala àrdūš ( arduš), iz evfemizirane variante prmejdun pa ärdûn ( - ardun).

(D) BD

Srvn. bî der sêle mîn 'bei meiner Seele = pri moji duši':
$\Rightarrow \mathrm{K} \operatorname{sln}$. *pri měji duši
$>$ *prmejduš
sln. prmejduš;
$\rightarrow \times$ ardigata

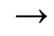
sln. prmejš;
$\rightarrow \times$ hardigata
sln. arduš;
$\rightarrow$ EVFEMIZIRANO Z Dunaj
sln. harduš;
$\rightarrow \times$ ardigata
$\rightarrow \times$ hardigata
$\rightarrow$ EVFEMIZIRANO S KRNITVIJO
sln. prmejdun;
sln. ardun;
sln. hardun;
sln. mejdun;
$\rightarrow$ EVFEMIZIRANO S kokoš
$\rightarrow$ PO HAPLOLOGIJI V DIAL.
sln. prmejkokoš;
sln. prmejkuš;
$\rightarrow$ EVFEMIZIRANO S KRNITVIJO
$\rightarrow$ EVFEMIZIRANO S KRNITVIJO
$\rightarrow$ POSODOBLJENO sln. *pri moji duši $>$ *prmojduš
$\rightarrow$ EVFEMIZIRANO Z Dunaj
sln. prmej;
sln. mejduš;
sln. prmojduš;
sln. primojdun.

- duša - moj $\Rightarrow$ prmejš $\Rightarrow$ arduš $\Rightarrow$ harduš $\Rightarrow$ prmejdun $\Rightarrow$ mejdun $\Rightarrow$ prmejkokoš $\Rightarrow$ prmejkuš $\Rightarrow$ prmej $\Rightarrow$ mejduš $\Rightarrow$ prmojduš $\Rightarrow$ primojdun

\section{prmejkokoš}

ESSJ Ø

prmëjkokộš interj za izražanje podkrepitve trditve, tudi prmejkokôš, npr. kaj pa morem, prmejkokoš, če je pijan (pog. šaljivo - SSKJ).

(T) Iz te kletvice je v narečnih sistemih z $\hat{o}>\hat{u}$ po skrajšanju nastala prmejkǔs, standardizirano kot prmëjkūš in prmejkūš interj za izražanje podkrepitve trditve, npr. prmejkuš, sedaj pa grem (pog. - SSKJ). Ni mogoče izključiti možnosti, da je skrajšanje posledica haplologije iz dial. refleksa *kukûš: *prmejkukûš > prmejkuš, npr. Prmejkuš, podkovanih karpov pa le nimate, kakor so bili nekdaj naši! (SN 28. 12. 1901, XXIV/298, 2; vir: dLib.si), Prmejkuš, zdaj pa pojdem še jaz med Tomaže, med neverne! (Kraigher, Mlada ljubezen, 1917; vir: IMP).

Isln. *prmej-kokộš interj.

() To je evfemizirana kletvica, ki je iz prvotne prmejduš nastala z zamenjavo izglasnega subst dúša kot enega temeljnih sestavin krščanske terminologije z nevtralnim, nebogokletnim kokộš 'gallina'.

\section{- prmejduš - kokoš}


prmejkuš $\rightarrow$ prmejkokoš

ESSJ Ø

prmojduš $\rightarrow$ prmejduš

ESSJ Ø

putrnica $\rightarrow$ butira

ESSJ Ø

snežni plažmec $\rightarrow$ plazem

ESSJ Ø

šica 1

ESSJ Ø

šica f 'potoček, ki priteče samo ob dežju, hudournik' (Žužemberk - SLA).

(O) Hdn Šica 'ime potoka, ki izvira pod vasjo Mala Račna v o. Grosuplje' (AS 1996), ‘ime potoka pri Jereslavcu v o. Brežice’ (AS 1996), 'ime potoka z občasno vodo južno od Stavče vasi v o. Novo mesto’ (AS 1996). Ni jasno, ali je dolenjski tpn Šíca 'ime naselja v o. Grosuplje', poknjižen kot Sušíca (SKI), nastal s transonimizacijo iz hdn.

IsIn. *sušica f 'vodni tok, ki je občasno suh'.

() Po redukciji prek *səšíca nastalo iz sušica 'hudournik' (Pleteršnik), to pa po univerbizaciji iz besednih zvez tipa *suha voda/reka k sûh 'siccus' < psl. *sûhb 'isto' (Pintar, LZ 33/12, 1913, 661), ki so tako kot kasneje simpleks označevala manjše vodne toke, ki so se občasno posušili.

\section{- suh}

ESSJ Ø

šica f 'učiteljica' (slovarsko neevidentirano).

Isln. *tovarišica učiteljica $\mathrm{f}$.

() $\mathrm{V}$ osnovno- in srednješolskem slengu druge polovice 20. stoletja uporabljana beseda, ki je bila skrajšana iz tršica 'učiteljica', kar je po redukciji nastalo iz tovarišica 'isto', to pa po elipsi iz tedaj zahtevanega uradnega naslavljanja tega poklica kot tovarišica učiteljica.

\section{- tovariš}

zora $^{2}$

ESSJ Ø

zo'ra f 'mozolj' (nad. (Marsin/Mersino) - SLA 1.1: 184).

Isln. *zorä f 'vnetje' $\rightarrow$ 'mozolj' (nad.).

() Ker je v slovenščini nad. zo'ra 'mozolj' hapaks legomenon, je verjetno, da se je v nadiškem mikrosistemu pomen 'mozolj' razvil iz prvotnega 'vnetje', ki ga potrjuje formalno enako nad. zorá (Špehonja 2003; Rigoni-Salvino 1999 s.v. infezione). Korenska povezanost s psl. *zorä f (ap C) 'aurora', nakazana v Horvat, SLA 1.2: 192, je sicer verjetna, a v semantičnem pogledu preveč oddaljena in zato nezadostna (Furlan, Annales 26/4, 2016, 632). Enak pomenski razvoj je treba predpostaviti tudi pri ter. zazôra 'tvor' (Breginj SLA 1.1: 182), prim. nad. zazòrjen 'vnet' ob zorá f 'vnetje'.

\section{- zoriti se}




\section{zoriti se}

ESSJ Ø

(se) zorit 'vneti (se)' (nad. - Špehonja 2003), ter. zoriti se 'gnojiti se', npr.

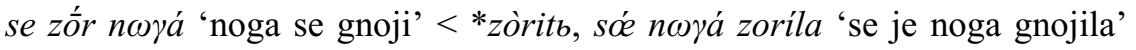
(Spinozzi Monai 2009: 357) <*zorila, ter. zoriti se -ín se 'gnojiti se (o nogi)' (Merkù GSTN).

(T) Ptc zazòrjen 'vnet' (nad. - Špehonja o.c.).

Psln. dial. *zorïti sę zòri(t) sę 'vneti se, gnojiti se' (zahodno (ter., nad.)).

- Prim. mak. zori 'peči se na šibkem ognju (o kruhu)', npr. neka zori lebot ušte malku 'naj se kruh še malo peče', se šireše miris na leb što zori ‘širil se je vonj po kruhu, ki se peče'.

< psl. dial. *zorïti 'segrevati, peči'/zorïti sę 'vneti se' (sln.-mak.).

() Gotovo pomenski odtenek v okviru psl. kavz *zoriti 'povzročati, da je (dovolj/ustrezno) zrelo = staro' (prim. gr. ptc prez akt $\gamma \varepsilon \dot{\varepsilon} \rho \omega v$ 'star, prileten' $\leftarrow^{*}$ 'zrel'), pri čemer se je pomen 'peči/vneti se' iz verjetno primarnega 'zoriti $=$ maturare $=$ reif machen' tako kot pri pide. *pek $u_{-}$' 'zoriti, kuhati, peči' (LIV': 468), prim. gr. $\pi \varepsilon \dot{\sigma} \sigma \omega$ 'mehčati, kuhati, peči, zoriti', $\delta \rho v-\pi \varepsilon \pi-\eta ́ \varsigma$ 'na drevesu zoreč', razvil na podlagi interpretacije, da se stanje zrelosti dosega z uporabo ognja, tj. s segrevanjem. Pomenski razvoj je zaradi sorodnega lit. žarijà ‘žar(enje), žerjavica, žareč premog’ (Smoczyński 2007: 779 brez slov. gradiva) lahko starejši od psl.

Sln. nad. zorá f 'vnetje' (Špehonja 1.c.; Rigoni-Salvino 1999 s.v. infezione) $\rightarrow$ nad. 'mozolj' ( zora $^{2}$ ) in ter. zazộra 'tvor' <*'vnetje' sta lahko mlada sln. dial. deverbativa.

\section{- zoriti}

\section{KRAJŠAVE IN SIMBOLI}

Krajšave in simboli, ki so bili uporabljeni že v geslih poskusnega zvezka NESSJ in rastočega spletnega slovarja NESSJ, se najdejo v Furlan 2013: 193-200, nove krajšave pa so tele:

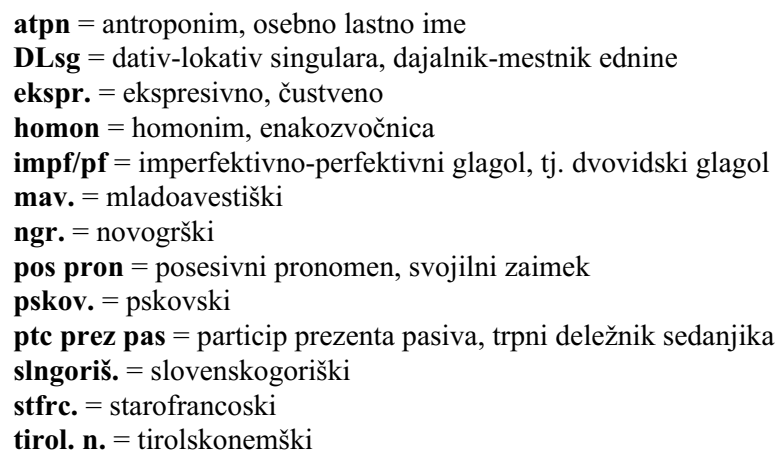




\section{VIRI IN LITERATURA}

Viri in literatura, ki so bili uporabljeni že v geslih poskusnega zvezka NESSJ in rastočega spletnega slovarja NESSJ, se najdejo v Furlan 2013: 175-192, novi pa so tile:

AS 1996 = Atlas Slovenije: 218 strani topografskih kart 1:50 000, letalski posnetki Slovenije, 44 mestnih načrtov, Ljubljana: Založba Mladinska knjiga - Geodetski zavod Slovenije, 1996.

Benko - Špolad Žuber 2008 = Marija Benko - Božica Špolad Žuber, Jedi na Kobariškem: kar je bujš, je pa bujš, Ljubljana: Kmečki glas, 2008.

Besedišče 1987 = Besedišče slovenskega jezika I-II: po kartoteki za slovar sodobnega knjižnega jezika zbrane besede, ki niso bile sprejete v Slovar slovenskega knjižnega jezika, sestavile Milka Bokal Milena Hajnšek-Holz - Marjeta Humar - Zvonka Praznik, uredili Milena Hajnšek-Holz - Marjeta Humar - Franc Jakopin, Ljubljana: Znanstvenoraziskovalni center SAZU, 1987.

Bezlaj ESSJ PZ 1963 = France Bezlaj, Etimološki slovar slovenskega jezika: poskusni zvezek, Ljubljana: Slovenska akademija znanosti in umetnosti, 1963.

Čujec Stres 2014 = Helena Čujec Stres, Slovar zatolminskega govora 2: $P-\check{Z}$, Zatolmin: Stres inženiring, 2014.

Darms 1978 = Georges Darms, Schwäher und Schwager, Hahn und Huhn: die Vrddhi-Ableitung im Germanischen, München: R. Kitzinger, 1978.

dLib.si = Digitalna knjižnica Slovenije 〈www.dlib.si $\rangle$.

ERHJ = Ranko Matasović - Tijmen Pronk - Dubravka Ivšić - Dunja Brozović Rončević, Etimološki rječnik hrvatskoga jezika 1: $A-N j$, Zagreb: Institut za hrvatski jezik i jezikoslovlje, 2016.

Erjavec 2014 = Zvonimir Erjavec, Raunagarska rīč: rječnik ravnogorsko-sušičko-španovačkoga dijalekta, Ravna Gora: Udruga Plodovi gorja Gorskog kotara - Općina Ravna Gora, 2014.

Filipi - Buršić Giudici 2012 = Goran Filipi - Barbara Buršić Giudici, Istromletački lingvistički atlas $(\operatorname{ImLA})=$ Atlante Linguistico Istroveneto $(A L I v)=$ Istrobeneški lingvistični atlas $($ IbLA), Zagreb: N. Dominović - Pula: Znanstvena udruga Mediteran - Sveučilište Jurja Dobrile, 2012.

Furlan 2013 = Metka Furlan, Novi etimološki slovar slovenskega jezika: poskusni zvezek, Ljubljana: Založba ZRC, ZRC SAZU, 2013.

Furlan 2016 = Metka Furlan, Prispevki k slovenski in slovanski etimologiji, Ljubljana: Založba ZRC, ZRC SAZU, 2016 (Linguistica et philologica 32).

Gutsman 1777 = Oswald Gutsmann, Windifche Sprachlehre, Klagenfurt: Ignaz Aloys Kleinmayer, 1777.

IMP = Jezikovni viri starejše slovenščine IMP $\langle\mathrm{http}: / / \mathrm{nl} . \mathrm{ijs} . \mathrm{si} / \mathrm{imp} /\rangle$.

Ivančič Kutin 2007 = Barbara Ivančič Kutin, Slovar bovškega govora, Ljubljana: Založba ZRC, ZRC SAZU, 2007.

JA = Archiv für slavische Philologie, Berlin, 1876-1929.

Janežič 1867 = Anton Janežič, Deutsch-slovenisches Taschen-Wörterbuch für Schule und Haus, Klagenfurt: E. Liegel, ${ }^{2} 1867$.

Janežič 1908 = Anton Janežič, Anton Janežič-ev slovensko nemški slovar: četrti, pomnoženi natis, priredil France Hubad, Celovec: Tiskarna Družbe sv. Mohorja, 1908.

Kartoteka SSKJ = Kartoteka Slovarja slovenskega knjižnega jezika, Leksikološka sekcija Inštituta za slovenski jezik Frana Ramovša ZRC SAZU v Ljubljani, hrani Arhiv Republike Slovenije.

Korenjak 2012 = Davorin Korenjak, Baldorja: zapis in slovar zahodnobriškega govora, Dobrovo v Brdih: samozaložba, 2012.

Linguistica $=$ Linguistica, Ljubljana, 1955-.

$\mathbf{L Z}=$ Ljubljanski zvon: leposloven in znanstven list, Ljubljana, 1881-1941.

Makowiecki 1936 = Stefan Makowiecki, Stownik botaniczny łacińsko-małoruski, Kraków: Polska Akademia Umiejętności, 1936.

Merkù GSTN = Pavle Merkù, Gradivo za slovar terskega narečja . - Rokopis, hrani Etimološko-onomastična sekcija Inštituta za slovenski jezik Frana Ramovša ZRC SAZU v Ljubljani. 
Miklosichiana 2013 = Miklosichiana bicentennalia: zbornik u čast dvestote godišnjice rođenja Franca Miklošiča, ur. Jasmina Grković-Mejdžor - Aleksandar Loma, Beograd: Srpska akademija nauka i umetnosti, 2013.

Miklošič 1875 = Franz Miklosich, Stammbildungslehre der slavischen Sprachen, Wien: Wilhelm Braumüller, 1875.

MR 2016 = Mari romanzi, mari del contatto: lessico e paretimologia, ur. Nikola Vuletić - Xosé Afonso Álvarez Pérez - José Enrique Gargallo Gil, Zadar: Sveučilište u Zadru, 2016.

Newerkla 2004 = Stefan Michael Newerkla, Sprachkontakte Deutsch - Tschechisch - Slowakisch: Wörterbuch der deutschen Lehnwörter im Tschechischen und Slowakischen: historische Entwicklung, Beleglage, bisherige und neue Deutungen, Frankfurt am Main idr.: Peter Lang, 2004.

Nikolaev - Tolstaja 2001 = Sergej L. Nikolaev - Marfa N. Tolstaja, Slovar' karpatoukrainskogo torun'skogo govora: s grammatičeskim očerkom i obrazcami tekstov, Moskva: Rossijskaja akademija nauk, Institut slavjanovedenija, 2001.

Pšajd 2005 = Jelka Pšajd, Še zdaj, na te sveti den, moreš preklinjati?: psovke in kletvice iz Pomurja in Porabja, Murska Sobota: Pokrajinski muzej Murska Sobota, 2005.

Ramovš 1952 = Fran Ramovš, Morfologija slovenskega jezika: skripta, prirejena po predavanjih prof. $d r$. F. Ramovša v l. 1947/48, 48/49, Ljubljana: DZS založila za Univerzitetno študijsko komisijo, 1952.

Rečnik BAN = Rečnik na bălgarskija ezik 1-, Sofija: Izdatelstvo na Bălgarskata akademija na naukite, 1977-.

Reichmayr 2003 = Michael Reichmayr, Ardigata! Krucinal!! ein slowenisches Schimpfwörterbuch, basierend auf Arbeiten von Josef Matl (1897-1974) zum deutsch-slawischen Sprach- und Kulturkontakt, Graz: Artikel-VII-Kulturverein für Steiermark - Laafeld: Pavelhaus = Potrna: Pavlova hiša, 2003.

RÉS $=$ Revue des études slaves, Paris 1921-.

RHKKJ = Rječnik hrvatskoga kajkavskoga književnog jezika 1-, Zagreb: Jugoslavenska akademija znanosti i umjetnosti, Zavod za jezik IFF, 1984-.

Rocchi 1990 = Luciano Rocchi, Latinismi e romanismi antichi nelle lingue slave meridionali, Udine: Campanotto Editore Udine, 1990.

Rystonová $\mathbf{2 0 0 7}$ = Ida Rystonová, Prưvodce lidovými názvy rostlin i jiných léčivých přirodnin a jejich produktì, Praha: Academia, 2007.

Sau 2009 = Silvano Sau, Dizionario del dialetto Isolano: raccolta di parole e modi di dire della parlata isolana di ieri, di oggi e, forse, di domani, Isola: Il Mandracchio, 2009.

Schatz 1955 = Josef Schatz, Wörterbuch der Tiroler Mundarten I-II, Innsbruck: Universitätsverlag Wagner, 1955.

Smoczyński 2007 = Wojciech Smoczyński, Stownik etymologiczny języka litewskiego, Wilno: Uniwersytet Wileński, 2007.

SN = Slovenski narod, Maribor - Ljubljana, 1868-1943.

Snoj 2016 = Marko Snoj, Slovenski etimološki slovar, Ljubljana: Založba ZRC, 32016.

Studia Borysiana 2014 = Studia Borysiana: Etymologica - Diachronica - Slavica: w 75. rocznice urodzin Profesora Wiestawa Borysia, ur. Mariola Jakubowicz - Beata Raszewska-Żurek, Warszawa: Instytut Slawistyki PAN - Fundacja Slawistyczna, 2014.

ŠM II = Škrabčeva misel 2: zbornik s simpozija '96, ur. Jože Toporišič, Nova Gorica: Frančiškanski samostan Kostanjevica, 1997.

Šulek 1874-1875 = Bogoslav Šulek, Hrvatsko-njemačko-talijanski rječnik znanstvenoga nazivlja 1-2, Zagreb: Tiskom narodne tiskarne Dra. Ljudevita Gaja, 1874-1875.

Todorović $\mathbf{2 0 1 7}$ = Suzana Todorović, Narečna raznolikost v okolici Kopra: Dekani, Hrvatini, Škofije, Koper: Libris, 2017.

Todorović 2018 = Suzana Todorović, Raznovrstnost narečnih govorov na Koprskem: Bertoki, Puče, Sveti Anton, Koper: Libris, 2018. 
Todorović - Koštiál 2014 = Suzana Todorović - Rožana Koštiál, Narečno besedje piranskega podeželja: Nova vas nad Dragonjo, Padna, Sveti Peter, Koper: Založba Annales, 2014.

TRMJ = Tolkoven rečnik na makedonskiot jazik 1-, Skopje: Institut za makedonski jazik »Krste Misirkov«, 2003-.

Večenaj - Lončarić 1997 = Ivan Večenaj - Mijo Lončarić, Srednjopodravska kajkavština: rječnik govora Gole, Zagreb: Institut za hrvatski jezik i jezikoslovlje, 1997.

WBÖ = Wörterbuch der bairischen Mundarten in Österreich 1-, Wien: Komissionsverlag der Österreichischen Akademie der Wissenschaften, 1970-.

Zb Jagić 1908 = Zbornik u slavu Vatroslava Jagića, Berlin: Weidmannsche Buchhandlung, 1908.

Zdovc 1972 = Paul Zdovc, Die Mundart des Südöstlichen Jauntales in Kärnten: Lautlehre und Akzent der Munart der »Poljanci«, Wien: Kommissionsverlag der Österreichischen Akademie der Wissenschaften, 1972.

Zudini - Dorsi 1981 = Diomiro Zudini - Pierpaolo Dorsi, Dizionario del dialetto muglisano, Udine: Casamassima Editore, 1981.

\section{SUMMARY}

\section{The New Slovenian Etymological Dictionary as a Growing Online}

\section{Dictionary: 2018 Additions}

This article presents seventy new headwords that at the end of 2018 will be added to Novi etimološki slovar slovenskega jezika (The New Slovenian Etymological Dictionary) as a growing online dictionary (2017-) available at the web portal Fran of the Fran Ramovš Institute of the Slovenian Language $\langle$ https://fran.si/207/nessj-novi-etimoloski-slovar-slovenskega-jezika/ $\rangle$. The lexicographic presentation of the etymologically processed vocabulary is based on the design presented in a pilot volume that advocates a non-nested format (Furlan 2013).

Novi etimološki slovar slovenskega jezika or NESSJ (The New Slovenian Etymological Dictionary) is an umbrella title for seminal etymological research on Slovenian that has been carried out by the Etymology and Onomastics Section of the Fran Ramovš Institute of the Slovenian Language (ZRC SAZU) since the completion of the first scholarly etymological dictionary - that is, France Bezlaj's Etimološki slovar slovenskega jezika I-V (Slovenian Etymological Dictionary, vols. 1-5; Ljubljana: Mladinska knjiga and Založba ZRC, 1976-2007). Extensive systemic processing of the Slovenian zoonymic lexicon is also being carried out under this umbrella title in parallel with the production of headwords for the growing online dictionary. This processing is being carried out by the author of this article. 